\title{
On the Role of Protonic Acid Sites in Cu Loaded FAU31 Zeolite as a Catalyst for the Catalytic Transformation of Furfural to Furan
}

\author{
Łukasz Kuterasiński *D, Małgorzata Smoliło-Utrata (D, Joanna Kaim, Wojciech Rojek, Jerzy Podobiński, \\ Katarzyna Samson, Dorota Duraczyńska, Małgorzata Zimowska (D), Mariusz Gackowski (D) and \\ Dorota Rutkowska-Zbik *(D)
}

Citation: Kuterasiński, Ł.; Smoliło-Utrata, M.; Kaim, J.; Rojek, W.; Podobiński, J.; Samson, K.; Duraczyńska, D.; Zimowska, M.; Gackowski, M.; Rutkowska-Zbik, D. On the Role of Protonic Acid Sites in $\mathrm{Cu}$ Loaded FAU31 Zeolite as a Catalyst for the Catalytic Transformation of Furfural to Furan. Molecules 2021, 26, 2015. https:// doi.org/10.3390/molecules26072015

Academic Editor: Serena Esposit

Received: 15 March 2021

Accepted: 29 March 2021

Published: 1 April 2021

Publisher's Note: MDPI stays neutra with regard to jurisdictional claims in published maps and institutional affiliations.

Copyright: (c) 2021 by the authors. Licensee MDPI, Basel, Switzerland. This article is an open access article distributed under the terms and conditions of the Creative Commons Attribution (CC BY) license (https:// creativecommons.org/licenses/by/ $4.0 /)$.
Jerzy Haber Institute of Catalysis and Surface Chemistry, Polish Academy of Sciences, Niezapominajek 8 , 30-239 Krakow, Poland; ncsmolil@cyf-kr.edu.pl (M.S.-U.); joanna.miasik@ikifp.edu.pl (J.K.); wojciech.rojek@ikifp.edu.pl (W.R.); ncpodobi@cyf-kr.edu.pl (J.P.); ncsamson@cyf-kr.edu.pl (K.S.); ncduracz@cyf-kr.edu.pl (D.D.); nczimows@cyf-kr.edu.pl (M.Z.); ncgackow@cyf-kr.edu.pl (M.G.)

* Correspondence: nckutera@cyf-kr.edu.pl (Ł.K.); dorota.rutkowska-zbik@ikifp.edu.pl (D.R.-Z.); Tel.: +48-12-6395-115 (Ł.K.); +48-12-6395-160 (D.R.-Z.)

Abstract: The aim of the present paper is to study the speciation and the role of different active site types (copper species and Brønsted acid sites) in the direct synthesis of furan from furfural catalyzed by copper-exchanged FAU31 zeolite. Four series of samples were prepared by using different conditions of post-synthesis treatment, which exhibit none, one or two types of active sites. The catalysts were characterized by XRD, low-temperature sorption of nitrogen, SEM, $\mathrm{H}_{2}-\mathrm{TPR}, \mathrm{NMR}$ and by means of IR spectroscopy with ammonia and CO sorption as probe molecules to assess the types of active sites. All catalyst underwent catalytic tests. The performed experiments allowed to propose the relation between the kind of active centers ( $\mathrm{Cu}$ or Brønsted acid sites) and the type of detected products (2-metylfuran and furan) obtained in the studied reaction. It was found that the production of 2-methylfuran (in trace amounts) is determined by the presence of the redox-type centers, while the protonic acid sites are mainly responsible for the furan production and catalytic activity in the whole temperature range. All studied catalysts revealed very high susceptibility to coking due to polymerization of furfural.

Keywords: faujasite; Brønsted acidity; copper; furan; furfural

\section{Introduction}

Furan is a heterocyclic organic compound whose molecule consists of a five membered aromatic ring formed by four carbon and one oxygen atoms. It is a precious precursor, mainly used in the production of chemicals such as $\alpha$-acetylfuran, 2,2-difurylpropane, pyrrole derivatives and many other compounds [1].

Furan may be produced using 1,3-butadiene or furfural as substrates. The first option is a partial oxidation of 1,3-butadiene in the vapor phase at $500{ }^{\circ} \mathrm{C}$ over $\mathrm{MoO}_{3}$ and $\mathrm{WO}_{3}$ catalysts, nevertheless the obtained furan yields are very poor (10-15\%) in spite of utilization of promoters such as $\mathrm{Mo}, \mathrm{Ni}$ and $\mathrm{Co}$ [1].

Production from furfural, which is the second option, can proceed via different routes, employing different classes of catalysts. Originally, furan was produced from furfural via furoic acid as an intermediate (Cannizzaro reaction), followed by decarboxylation to produce furan [2]. More straightforward way is a direct decarbonylation of furfural with a release of a molecule of carbon monoxide (see Figure 1 [3]), the process that may be treated as a side reaction during the hydrogenation of furfural $[3,4]$. 


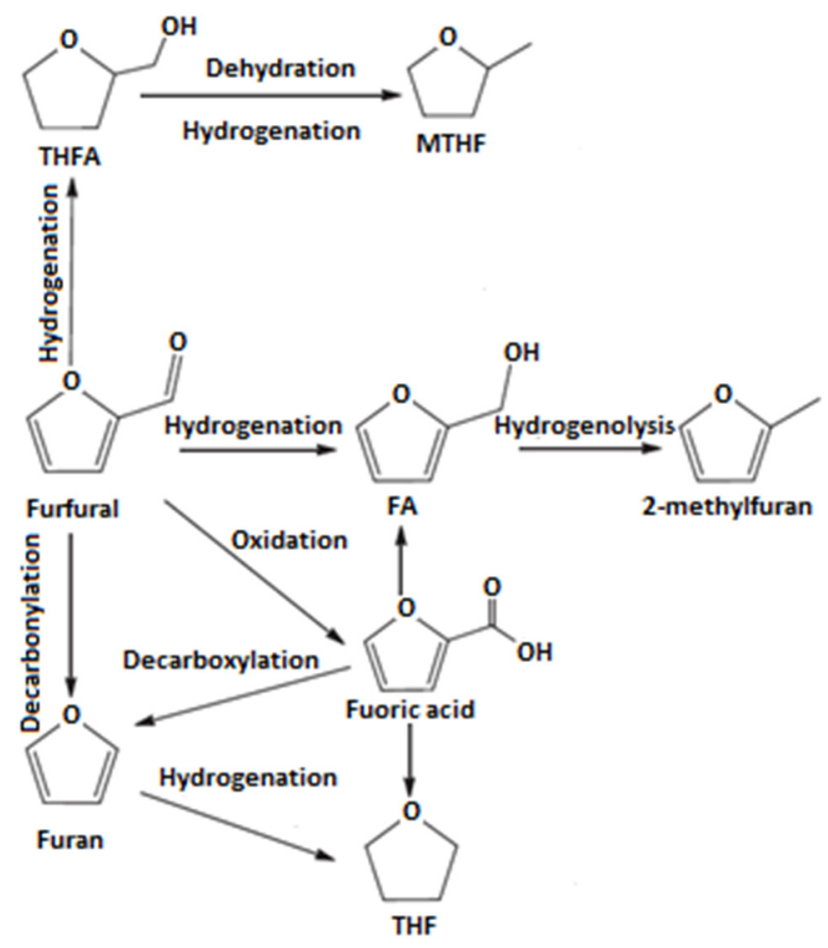

Figure 1. Possible pathways of hydrogenation of furfural based on data from [3].

Most of reports describe the use of precious metals as catalysts. The decomposition of furfural into furan was investigated over Pd catalysts either in liquid or vapor phase in the temperature range of $150-250{ }^{\circ} \mathrm{C}[5,6]$. Singh et al. [3,7] studied decarbonylation of furfural over $\mathrm{Pd} / \mathrm{C}$ and $\mathrm{Pd} / \mathrm{Al}_{2} \mathrm{O}_{3}$, out of which carbon was better carrier than $\mathrm{Al}_{2} \mathrm{O}_{3}$. It was found that the presence of hydrogen enhanced the furan yield and promoted the transport process of the reagents to/from the active sites in catalysts. Furan was also obtained by heating of furfural at $160{ }^{\circ} \mathrm{C}$ in the presence of $5 \% \mathrm{Pd}$ supported on microporous carbon and potassium carbonate (furan yields over 98\%) [3,8]. In turn, Bhogeswararao and Srinivas [9] used $\mathrm{Pt} / \mathrm{Al}_{2} \mathrm{O}_{3}$ catalyst for which maximum furan yield was $50 \%$ at $240{ }^{\circ} \mathrm{C}$.

Other, non-noble metal catalysts were tested as well. Wilson [3,10] described the production of furan from furfural over nickel gauze catalyst (yields $>50 \%$ ). Decomposition of furfural into furan was also studied by Lejemble et al. $[3,11]$ in the presence of steam over metal oxide catalysts, such as $\mathrm{Zn} / \mathrm{Fe}$ or $\mathrm{Zn} / \mathrm{Mn}$ chromite at $400{ }^{\circ} \mathrm{C}$. High temperature may lead to the ring opening of furan towards heavy products and carbon deposit on the surface of catalyst. Hurd et al. [3,12] reported direct production of furan from furfural over fused alkali (with yields up to $60 \%$ ) and the pyrolysis of furfural (yields ca.16.5\%).

Next, production of furan from furfural was tested over systems containing acid sites such as present in zeolites (at 300-500 ${ }^{\circ} \mathrm{C}$ ). Fanchiang and Lin [13] studied H-ZSM-5 and $\mathrm{Zn} / \mathrm{H}-\mathrm{ZSM}-5$-based catalysts in a continuous fixed bed system. The reaction temperature, contact time and the presence of promoters were crucial for the manipulation of final products composition. At 300, 400 and $500{ }^{\circ} \mathrm{C}$, furan yields were $16.5 \%, 30.6 \%$ and $19.5 \%$ respectively. Doping H-ZSM-5 with $1.5 \% \mathrm{Zn}$ led to increase of furan yields at lower temperatures and disappearance of furan at $500{ }^{\circ} \mathrm{C}$ in comparison to the H-ZSM-5 system. For Zn-containing sample, furan yields were $30.7 \%, 45.0 \%$ and $0 \%$ at 300, 400 and $500{ }^{\circ} \mathrm{C}$, respectively.

Finally, catalysts combining acid and metal active sites were also investigated. Seo and Chon [14] tested furfural hydrogenation in a fixed-bed stainless-steel tubular integral reactor at $160-350{ }^{\circ} \mathrm{C}$ in the presence of Pd-HY and Pd-LaY. The obtained furan yields were 50 and 38\%, respectively. Taking into account that HY and LaY possess strong Brønsted acid sites $[15,16]$, it was postulated that the presence of furan resulted from the interaction 
between polar carbonyl group of furfural and zeolitic acid sites. Pd probably activated the hydrogen [14].

Analysis of literature prompted us to take part in the discussion concerning the nature and contribution of various types of active centers, metallic "redox" type and acidic ones, in the mechanism of furfural to furan transformations. To do so, we have prepared samples containing FAU31 zeolite modified with copper species as the catalyst for the abovementioned reaction, which have one or two of the discussed active centers: Brønsted acid sites related to the zeolite structure as well as the "redox" type copper species (playing also a role of Lewis acid sites). We aimed at defining the role of particular active center in furfural to furan reaction by the systematic studies of catalytic activity of the prepared samples.

The chosen zeolite, HFAU31, is a commercial material with faujasite type structure after both ultrastabilization and partial dealumination $(\mathrm{Si} / \mathrm{Al}=31)$. Strength of acid sites present in FAU31 is higher in relation to the ones present in other zeolites, which are widely used in chemical industry like MFI, BEA or MOR [17].

Copper-containing zeolites are commonly used as active catalysts for numerous chemical processes, mostly "DeNOx", but also oxidation, isomerization and dehydration [18-27], and thus, their properties were the subject on subject of very extensive studies: see, e.g., [28-36]. Copper active sites play an important role in activation of unsaturated bonds: double carbon-carbon bonds in alkenes, triple carbon-carbon bonds in ethyne, $\mathrm{C}=\mathrm{O}$ bonds in acetone and formaldehyde as well as aromatic bonds in benzene [37-40]. Further, the IR and quantum mechanics studies [41,42] evidenced strong activation of hydrogen by $\mathrm{Cu}$ ions in zeolites. As a result, zeolites with copper were used for the one-pot production of dimethylether by hydrogenation of $\mathrm{CO}$ and $\mathrm{CO}_{2}$ over hybrid catalysts: $\mathrm{CuZnAl} / \mathrm{ZSM}-5$ and CuZrZn/ferrierite [43,44].

\section{Results and Discussion}

\subsection{Structure of the Studied Catalysts}

The X-ray diffraction (XRD) patterns collected for the studied catalysts are presented in Figure 2. For all samples the presence of FAU type phase was found [45]. The way of the catalyst modification plays an important role in the crystallinity of the final form of the samples. FAU31-based catalysts impregnated with $\mathrm{Cu}$ solution $\left(\mathrm{Cu}_{\mathrm{x}} \mathrm{H}-\mathrm{Z}\right)$ are characterized by lower crystallinity (57-73\%) in respect to the parent sample (H-Z-100\%). The crystallinity loss depended weakly on the amount of the introduced copper.

Another effect was observed in case of the samples pretreated with sodium nitrate series (Na-Z). The application of the procedure referring to the removal of Brønsted acid sites with $\mathrm{NaNO}_{3}(\mathrm{pH}=7)$ led to a significant deterioration of zeolite crystallinity (from 100 to $23 \%)$. Further treatment with copper $\left(\mathrm{Cu}_{x} \mathrm{Na}-\mathrm{Z}\right)$ leads to no apparent changes in the crystallinity of the samples (28-30\%).

The explanation of the observed effect seems to be complex. At first sight, observed phenomenon could be explained as a result of hydrolysis of Si-O-Al groups occurring in zeolites [46]. $\mathrm{H}-\mathrm{Z}$ treated with a pure distilled water (at the same $\mathrm{pH}$ and temperature) subjected to a distinct decrease of crystallinity (from 100 to 39\%). On the other hand, it is worth emphasizing that the partially dealuminated $\mathrm{H}-\mathrm{Z}$ (used here as a parent sample) has a fractured structure, which is more sensitive to any modification in relation to the virgin FAU, as shown by Gackowski et al. [17,47]. That leads to the amorphization of the "nibbled" FAU-type zeolite.

Observed differences in the crystallinity loss of the final form of prepared samples depending on the chemical composition of used mixture for $\mathrm{H}-\mathrm{Z}$ modification might be associated with an ionic strength of the employed aqueous solutions. Further research concerning this matter will be continued. 

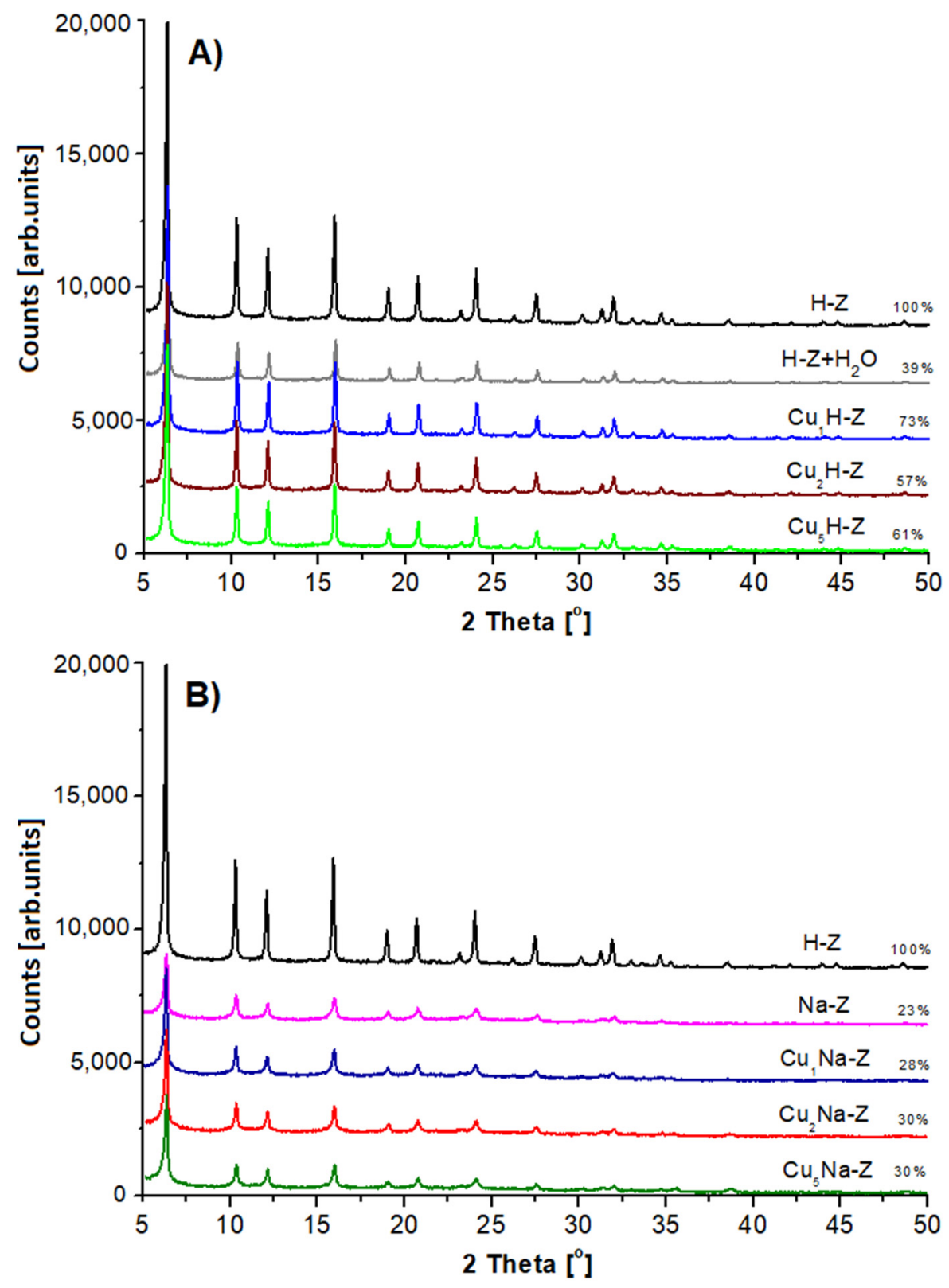

Figure 2. Powder XRD patterns of modified zeolites: (A) samples modified only with $\mathrm{Cu}\left(\mathrm{NO}_{3}\right)_{2} \cdot 3 \mathrm{H}_{2} \mathrm{O}$; (B) samples pretreated with $\mathrm{NaNO}_{3}$ and then modified with $\mathrm{Cu}\left(\mathrm{NO}_{3}\right)_{2} \cdot 3 \mathrm{H}_{2} \mathrm{O}$.

For all $\mathrm{Cu}$-zeolites (both $\mathrm{Cu}_{\mathrm{x}} \mathrm{H}-\mathrm{Z}$ and $\mathrm{Cu}_{x} \mathrm{Na}-\mathrm{Z}$ ), no XRD patterns of copper phase were found. This indicates that the incorporated copper forms crystals, which can be too difficult for identification by this technique.

${ }^{27} \mathrm{Al}$ MAS NMR spectra of the parent and modified samples are visualized in Figure 3. The employed modification procedures have an influence on the status of aluminum.

Spectrum of the parent H-Z shows two signals: at 61.4 ppm related to "zeolitic" tetrahedral $\mathrm{Al}$ and at $0 \mathrm{ppm}$ associated with octahedrally coordinated extraframework $\mathrm{Al}$.

Treatment of $\mathrm{H}-\mathrm{Z}$ either with $\mathrm{NaNO}_{3}$ or $\mathrm{Cu}\left(\mathrm{NO}_{3}\right)_{2} \cdot 3 \mathrm{H}_{2} \mathrm{O}$ leads to the disappearance of the signal at $0 \mathrm{ppm}$ coming from extraframewok Al. Simultaneously, a new signal at ca. $-53 \mathrm{ppm}$ appeared. The signal is typical of tetrahedral (non-zeolitic) Al present in amorphous aluminosilicates, which was also reported by Gackowski et al. [17] and Kuterasinski et al. [48]. This signal is particularly strong in the spectra of the sample modified with $\mathrm{NaNO}_{3}$ alone (Na-Z), for which the most noticeable decrease of crystallinity was found. Hence, it may be concluded that the contribution of this type of aluminum 
species increases with the amorphization of parent H-Z zeolite [49]. Another possibility is the change of the status of aluminum as a result of the interaction between $\mathrm{Al}$ species coming from zeolitic structure and extraframework cations originating from modifiers, such as pyridine, ammonia and salts $\left(\mathrm{Na}^{+}\right.$or $\left.\mathrm{K}^{+}\right)$, which was reported by Bourgeat et al. [50]. Based on the data summarized in [50], we may conclude that similar situation in the case of the treatment of our FAU-type zeolite with aqueous $\mathrm{Cu}\left(\mathrm{NO}_{3}\right)_{2}$ solution takes place.

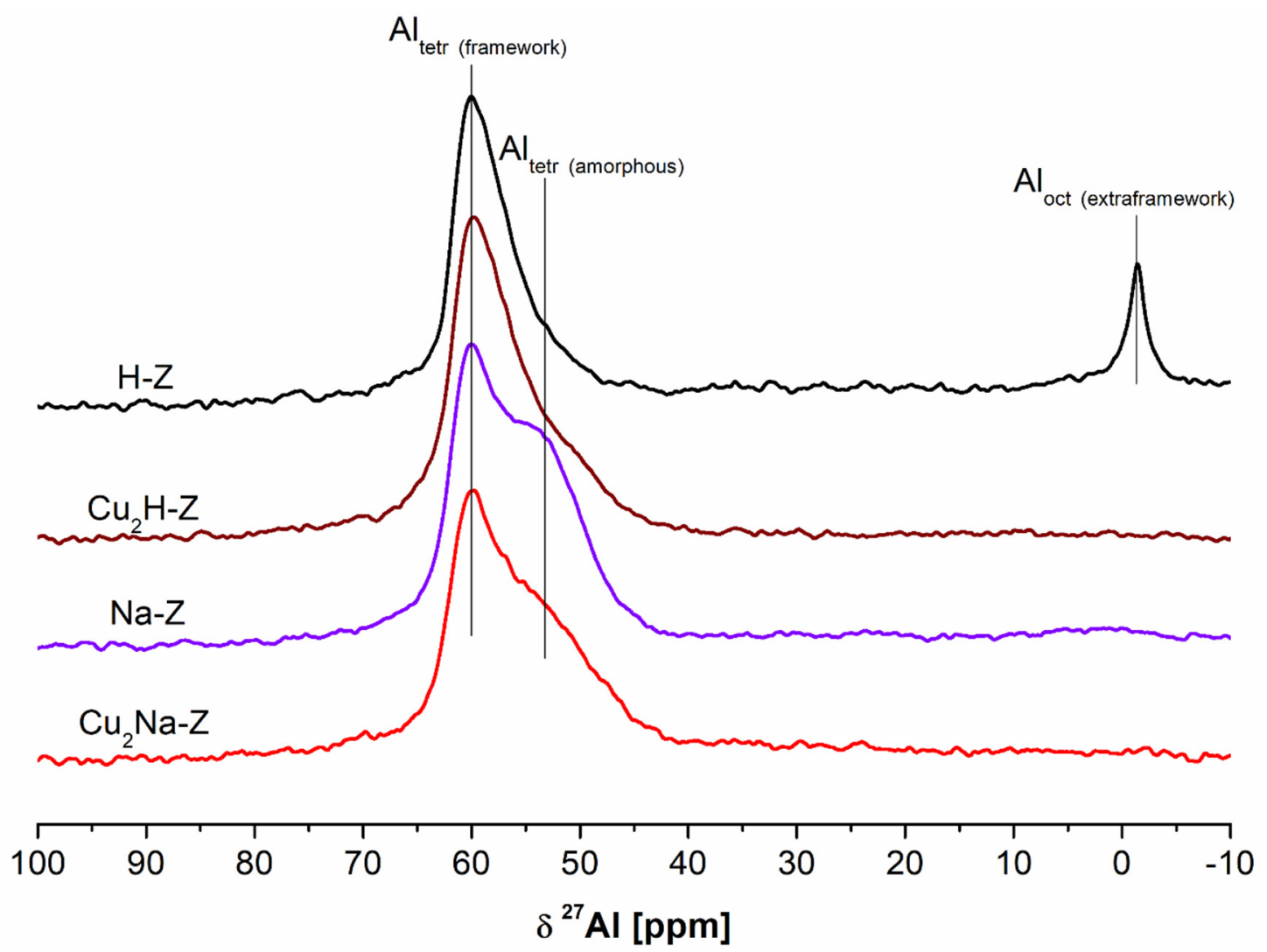

Figure 3. ${ }^{27} \mathrm{Al}$ NMR spectra of different prepared samples.

\subsection{Porosity of the Prepared Catalysts}

The porosity of the studied samples is presented in Table 1 . The parent H-Z zeolite contained both micropores (the volume of which was $0.26 \mathrm{~cm}^{3} / \mathrm{g}$ ) and mesopores $\left(0.29 \mathrm{~cm}^{3} / \mathrm{g}\right)$. The external surface area and average pore diameter were $278 \mathrm{~m}^{2} / \mathrm{g}$ and $29.0 \AA$, respectively.

Table 1. EDS (Energy Dispersive Spectroscopy) chemical analysis, $\mathrm{N}_{2}$ physisorption derived properties and the influence of $\mathrm{Cu}$ content on the concentration of active centers in the studied samples.

\begin{tabular}{|c|c|c|c|c|c|c|c|c|c|c|c|}
\hline \multirow[b]{2}{*}{ Sample } & \multicolumn{4}{|c|}{ Chemical Analysis (EDS) } & \multicolumn{4}{|c|}{ Porosity } & \multicolumn{3}{|c|}{ Acidity } \\
\hline & Si [\%] & Al [\%] & $\mathrm{O}[\%]$ & $\mathrm{Cu}[\%]$ & $\begin{array}{l}V_{\text {micro }} \\
{\left[\mathrm{cm}^{3} / \mathrm{g}\right]}\end{array}$ & $\begin{array}{l}V_{\text {meso }} \\
{\left[\mathrm{cm}^{3} / \mathrm{g}\right]}\end{array}$ & $\begin{array}{c}S_{\text {EXT }} \\
{\left[\mathrm{m}^{2} / \mathrm{g}\right]}\end{array}$ & $\mathrm{D}[\AA ̊ \mathbf{A}]$ & $\begin{array}{c}\text { BAS } \\
{[\mu \mathrm{mol} / \mathrm{g}]}\end{array}$ & $\begin{array}{c}\text { LAS } \\
{[\mu \mathrm{mol} / \mathrm{g}]}\end{array}$ & $\begin{array}{c}\mathrm{Cu}^{+} \\
{[\mu \mathrm{mol} / \mathrm{g}]}\end{array}$ \\
\hline $\mathrm{H}-\mathrm{Z}$ & 23.5 & 0.7 & 75.8 & 0 & 0.260 & 0.290 & 278 & 29.0 & 160 & 90 & 0 \\
\hline $\mathrm{Cu}_{1} \mathrm{H}-\mathrm{Z}$ & 27.3 & 1.1 & 70.7 & 0.9 & 0.218 & 0.292 & 280 & 29.9 & 80 & 211 & 75 \\
\hline $\mathrm{Cu}_{2} \mathrm{H}-\mathrm{Z}$ & 29.4 & 0.8 & 67.2 & 2.6 & 0.222 & 0.293 & 296 & 29.1 & 20 & 314 & 160 \\
\hline $\mathrm{Cu}_{5} \mathrm{H}-\mathrm{Z}$ & 26.7 & 0.6 & 69.6 & 3.1 & 0.213 & 0.283 & 289 & 28.9 & 0 & 441 & 170 \\
\hline Na-Z & 24.4 & 0.9 & 73.7 & 0 & 0.154 & 0.594 & 529 & 36.7 & 0 & 249 & 0 \\
\hline $\mathrm{Cu}_{1} \mathrm{Na}-\mathrm{Z}$ & 23.1 & 1.3 & 73.4 & 1.0 & 0.126 & 0.546 & 458 & 38.8 & 0 & n.m. & 30 \\
\hline $\mathrm{Cu}_{2} \mathrm{Na}-\mathrm{Z}$ & 23.3 & 1.6 & 73.3 & 1.1 & 0.129 & 0.516 & 443 & 37.8 & 0 & n.m. & 30 \\
\hline $\mathrm{Cu}_{5} \mathrm{Na}-\mathrm{Z}$ & 27.7 & 1.4 & 68.5 & 1.5 & 0.131 & 0.536 & 459 & 38.0 & 0 & n.m. & 30 \\
\hline
\end{tabular}


The choice of the post-synthesis modification had a pronounced effect on the porous structure of the studied samples. The direct modification of $\mathrm{H}-\mathrm{Z}$ with $\mathrm{Cu}\left(\mathrm{Cu}_{\mathrm{x}} \mathrm{H}-\mathrm{Z}\right)$ causes slight increase of external surface area from 278 to $280-296 \mathrm{~m}^{2} / \mathrm{g}$ and small loss of the micropore volume from 0.26 to $0.21 \mathrm{~cm}^{3} / \mathrm{g}$. Neither the volume of mesopores nor average pore diameter were changed.

The utilization of $\mathrm{NaNO}_{3}$ to obtain the sodium form of $\mathrm{H}-\mathrm{Z}(\mathrm{Na}-\mathrm{Z})$ led to significant loss of microporous structure. The volume of micropores decreased from 0.26 to $0.15 \mathrm{~cm}^{3} / \mathrm{g}$ with a simultaneous increase of mesopores volume from 0.29 to $0.59 \mathrm{~cm}^{3} / \mathrm{g}$. The external surface area and average pore diameter increased from 278 to $529 \mathrm{~m}^{2} / \mathrm{g}$ and from 29.0 to $36.7 \AA$, respectively. The observed changes in the porosity of $\mathrm{Na}-\mathrm{Z}$ in relation to parent $\mathrm{H}-\mathrm{Z}$ may result from the destruction of microporosity and the simultaneous production of larger mesoporous pores.

Further treatment with aqueous copper nitrate solution leads to small changes in the porous structure of such modified samples $\left(\mathrm{Cu}_{\mathrm{x}} \mathrm{Na}-\mathrm{Z}\right)$. Both an external surface area and the volume of mesopores for $\mathrm{Cu}$-containing samples were smaller in comparison with Na-Z: (443-459 $\mathrm{m}^{2} / \mathrm{g}$ vs. $529 \mathrm{~m}^{2} / \mathrm{g}$ and $0.52-0.55 \mathrm{~cm}^{3} / \mathrm{g}$ vs. $0.59 \mathrm{~cm}^{3} / \mathrm{g}$, respectively).

\subsection{Morphology of the Studied Samples}

The scanning electron micrographs of the variously modified samples are presented in Figure 4 and TEM images are additionally included in Appendix A Figure A5. The FAU31based catalyst particles are of irregular shape. However, in the case of parent sample $(\mathrm{H}-\mathrm{Z})$ grains are prisms and are characterized by sharp and clear edges. Either for the sample directly modified with $\mathrm{Cu}$ species $\left(\mathrm{Cu}_{5} \mathrm{H}-\mathrm{Z}\right)$ or pretreated with $\mathrm{NaNO}_{3}$ and then modified with $\mathrm{Cu}\left(\mathrm{NO}_{3}\right)_{2}\left(\mathrm{Cu}_{5} \mathrm{Na}-\mathrm{Z}\right)$, some amorphization took place. That resulted in the blurring of the prism-shaped crystals with sharp edges into streamlined agglomerates of amorphized zeolite grains. From SEM micrographs, it may be concluded that copper active phase is generally well distributed over a zeolitic carrier. Only a very small part of copper formed clusters. That is in line with XRD images (Figure 2), for which no additional reflexes attributed to copper phase were observed.

Table 1 presents the spatial distribution of selected elements: $\mathrm{Si}, \mathrm{Al}, \mathrm{O}$ and $\mathrm{Cu}$ for all prepared samples. The EDS analysis leads to the conclusion that the treatment of parent zeolite $(\mathrm{H}-\mathrm{Z})$ with either $\mathrm{NaNO}_{3}$ or $\mathrm{Cu}\left(\mathrm{NO}_{3}\right)_{2}$ did not cause relevant changes in chemical composition of bare zeolitic carrier. The amounts of $\mathrm{Si}, \mathrm{Al}$ and $\mathrm{O}$ were in the ranges of 23.3-27.7\%wt., 0.6-1.6\%wt. and 67.2-75.8\%wt., respectively. When the copper was taken into account in our considerations, it was found that copper content detected by EDS depended on the way of samples preparation $\left(\mathrm{Cu}_{\mathrm{x}} \mathrm{H}-\mathrm{Z}\right.$ vs. $\left.\mathrm{Cu}_{\mathrm{x}} \mathrm{Na}-\mathrm{Z}\right)$. For protonic series, the amount of copper found by EDS increased with the real amount of copper introduced into FAU-type zeolite by the impregnation procedure. Comparison of the coper contents from EDS and really introduced by the impregnation $(0.9 \% w t$. or $2.6 \%$ wt. or $3.1 \%$ wt. vs. $1.0 \%$ wt. or $2.0 \%$ wt. and $5.0 \%$ wt., respectively) led to the conclusion that the great majority of copper was located on the surface zeolitic grains. Another situation took place in the case of sodium series: Copper content found by EDS depended weakly on the real amount of $\mathrm{Cu}$ deposited on the zeolite during the impregnation and was in the range of $1.0-1.5 \%$ wt. Hence, particularly for the sample containing $5 \%$ wt. of copper $\left(\mathrm{Cu}_{5} \mathrm{Na}-\mathrm{Z}\right)$, most of copper was located within such modified zeolitic grains and was inaccessible for the detection by EDS technique. 

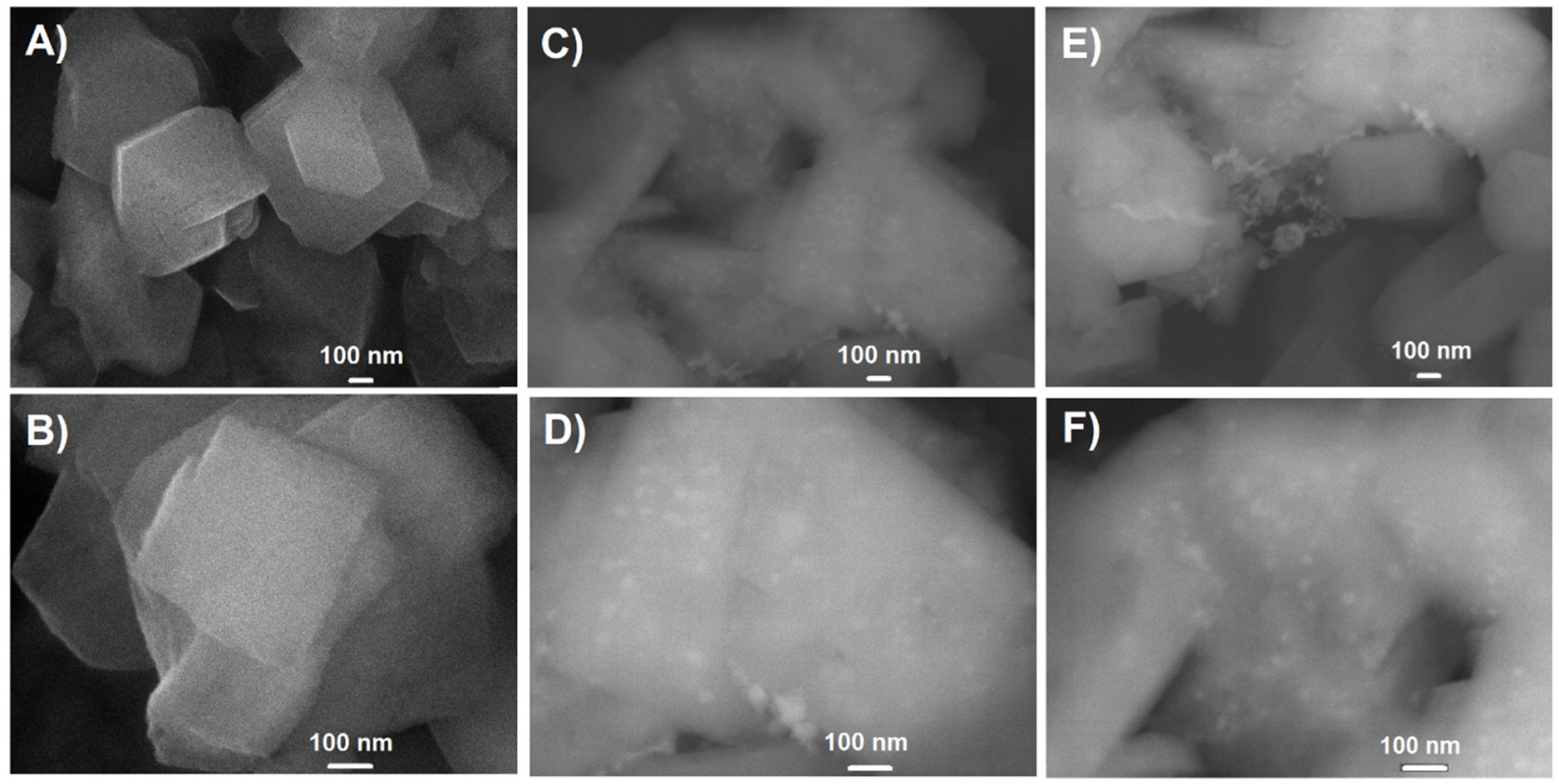

Figure 4. SEM images of the chosen samples: $\mathrm{H}-\mathrm{Z}$ as a parent sample: (A) 50,000 x, (B) 100,000 x; Cu각-Z sample: (C) 50,000 x, (D) 100,000 x; Cu5Na-Z sample: (E) 50,000 x, (F) 100,000 x.

\subsection{Reducibility of the Catalysts}

Figure 5 shows $\mathrm{H}_{2}$-TPR profiles of the prepared samples. Generally, the size and the position of the reduction peaks depended both on the copper content and on the preparation method of the catalyst. No reduction peaks were found for the catalysts with $1 \%$ wt. of Cu probably due to too low amount of the active phase. For the samples with $2 \%$ wt. of $\mathrm{Cu}$, pretreatment with sodium nitrate and subsequent impregnation with $\mathrm{Cu}$ $\left(\mathrm{Cu}_{2} \mathrm{Na}-\mathrm{Z}\right)$ resulted in the occurrence of the reduction peak with the maximum at the similar temperature $\left(321^{\circ} \mathrm{C}\right)$ in relation to the sample directly modified with copper nitrate $\left(\mathrm{Cu}_{2} \mathrm{H}-\mathrm{Z}\right)$, for which maximum was found at $325^{\circ} \mathrm{C}$. Further increase of the amount of $\mathrm{Cu}$ in the samples resulted in the appearance of bigger reduction peaks. The way of modification of the studied samples had not the influence on the shape of the reduction peaks. In the case of $\mathrm{Cu}_{5} \mathrm{H}-\mathrm{Z}$, the obtained signal with maximum at $310^{\circ} \mathrm{C}$ was greater than the signal registered for $\mathrm{Cu}_{5} \mathrm{Na}-\mathrm{Z}$ with maximum localized at $320^{\circ} \mathrm{C}$. In all cases the obtained wide reduction peaks may be assigned to $\mathrm{Cu}^{2+} \rightarrow \mathrm{Cu}^{0}$ [51-55].

\subsection{Character of the Active Sites as Evidenced by IR Spectroscopy with $\mathrm{CO}$ and $\mathrm{NH}_{3}$ as Probe Molecules}

Figure 6 shows the differential IR spectra recorded for the samples activated at $400{ }^{\circ} \mathrm{C}$ and after adsorption of ammonia at $130^{\circ} \mathrm{C}$. In the case of $\mathrm{H}-\mathrm{Z}, \mathrm{Cu}_{1} \mathrm{H}-\mathrm{Z}$ and $\mathrm{Cu}_{2} \mathrm{H}-\mathrm{Z}$, the presence of Brønsted acid sites was evidenced. Raising $\mathrm{Cu}$ content causes a decrease of the intensity of the bands at 3620,3550 and $1450 \mathrm{~cm}^{-1}$ assigned to the acidic $\mathrm{OH}$ groups from the zeolite structure. That implies from ionic-exchange of protons by copper cations. Simultaneously, the increase of $1620 \mathrm{~cm}^{-1}$ band intensity related to Lewis acid sites was found. The occurrence of Lewis acid sites originated both from aluminum in FAU31-type zeolite as well as from the copper species [56-58]. In this case, the introduction of copper species into FAU31-zeolite structure is responsible for the increase of Lewis acidity. For H-Z, $\mathrm{Cu}_{1} \mathrm{H}-\mathrm{Z}, \mathrm{Cu}_{2} \mathrm{H}-\mathrm{Z}$ and $\mathrm{Cu}_{5} \mathrm{H}-\mathrm{Z}$, concentrations of Brønsted and Lewis acid sites formed the following sequences: (160 vs. $90 \mu \mathrm{mol} / \mathrm{g}),(80 \mathrm{vs} .211 \mu \mathrm{mol} / \mathrm{g}),(20 \mathrm{vs} .314 \mu \mathrm{mol} / \mathrm{g})$ and $(0$ vs. $441 \mu \mathrm{mol} / \mathrm{g}$ ), respectively (Table 1$)$. $\left(\mathrm{Cu}_{\mathrm{x}} \mathrm{H}-\mathrm{Z}\right)$. In all cases the presence of terminal $\mathrm{OH}$ group was detected (see bands at $3740 \mathrm{~cm}^{-1}$ ). The sample treated with $\mathrm{NaNO}_{3}(\mathrm{Na}-\mathrm{Z})$ was deprived of protonic acidity—no bands at 3620,3550 and $1450 \mathrm{~cm}^{-1}$ were found. 


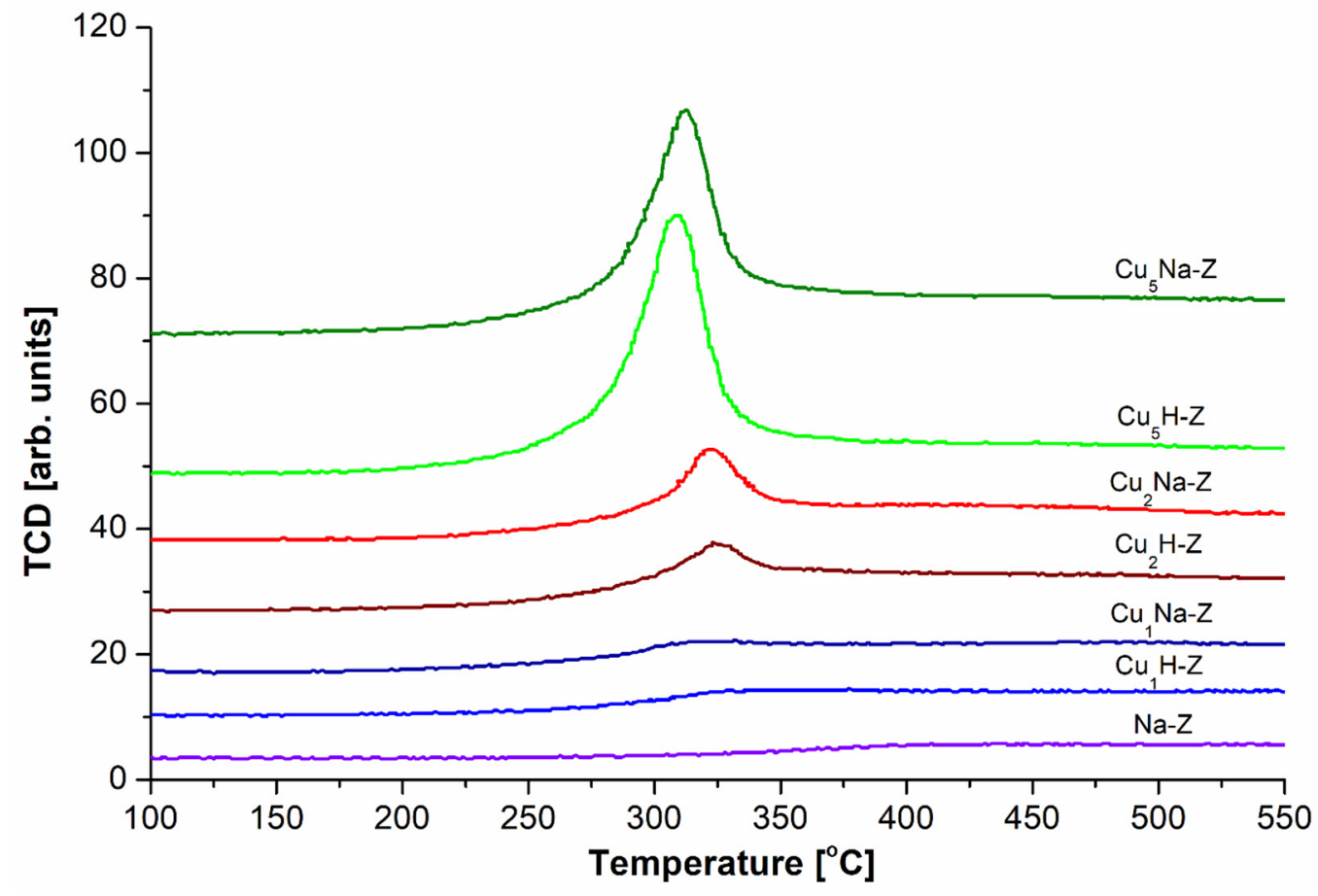

Figure 5. $\mathrm{H}_{2}$-TPR profiles for $\mathrm{Cu}$-containing zeolites.

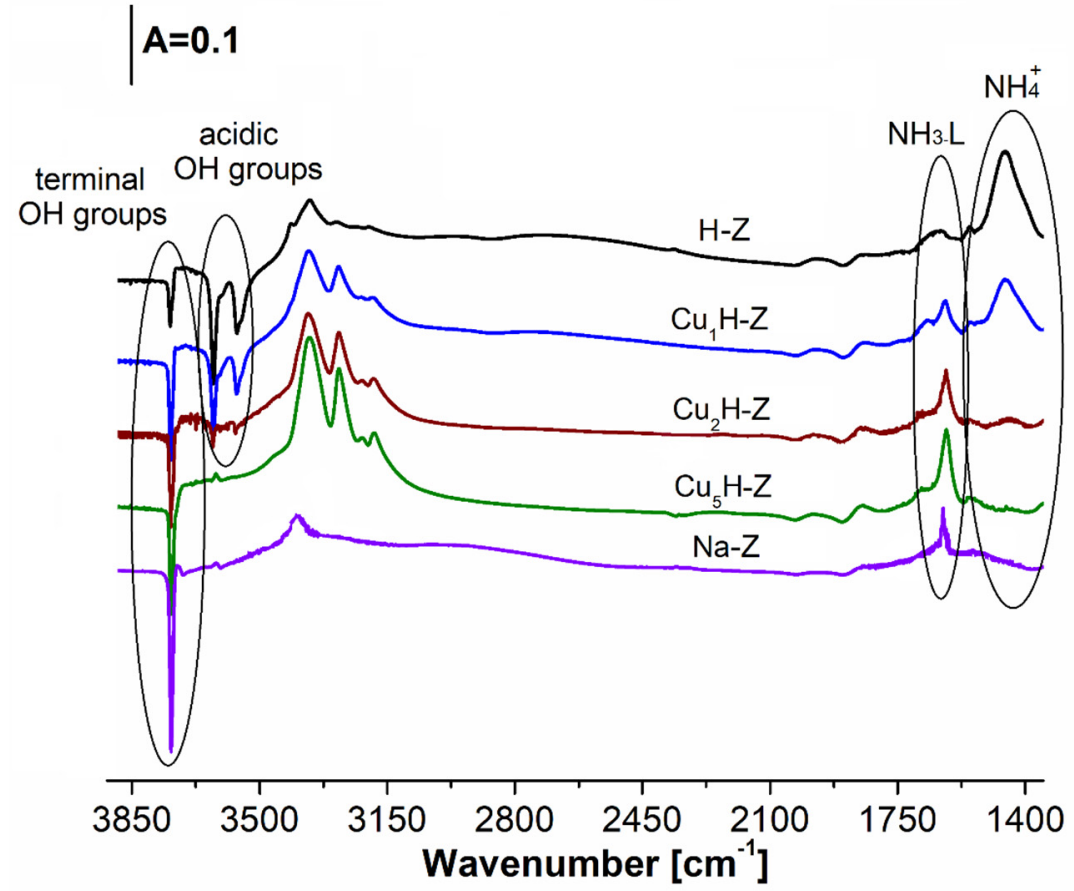

Figure 6. The co-existence of Brønsted and Lewis acid sites in dependence on the modification procedure of catalysts.

The results from the differential IR spectra and the quantitative analysis obtained from the experiments with the $\mathrm{CO}$ adsorption on the $\mathrm{Cu}$-containing samples at room temperature are reported in Figure 7 and Table 1. For the samples directly impregnated with copper $\left(\mathrm{Cu}_{x} \mathrm{H}-\mathrm{Z}\right)$, the increasing $\mathrm{Cu}$ content from $1 \%$ wt. to $2 \%$ wt. led to much higher concentration of $\mathrm{Cu}^{+}$(from 75 to $160 \mu \mathrm{mol} / \mathrm{g}$ ). Further rising of the amount of copper up to $5 \%$ wt. had no additional effect ( $160 \mathrm{vs}$. $170 \mu \mathrm{mol} / \mathrm{g})$. It may be concluded that 
the cationic exchange positions were filled fully by $\mathrm{Cu}^{+}$present in high amount in the FAU-based samples.

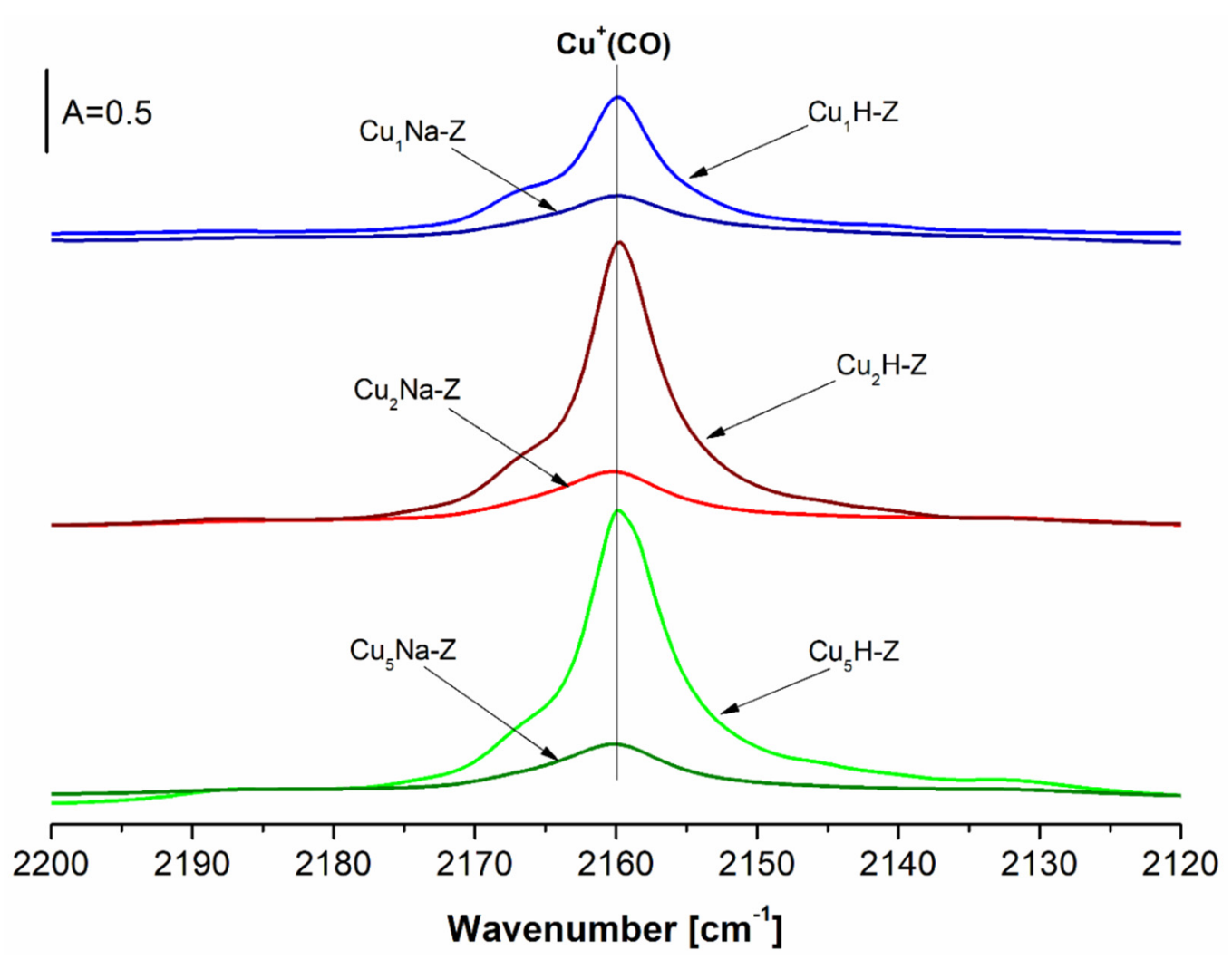

Figure 7. IR spectra of $\mathrm{CO}$ adsorbed at $25^{\circ} \mathrm{C}$ on the surface of $\mathrm{Cu}$-zeolite samples.

The data obtained for the zeolites pretreated with $\mathrm{NaNO}_{3}$ and then modified with $\mathrm{Cu}$ $\left(\mathrm{Cu}_{\mathrm{x}} \mathrm{Na}-\mathrm{Z}\right)$ indicated low concentration of $\mathrm{Cu}^{+}(\mathrm{ca} 30 \mu \mathrm{mol} / \mathrm{g})$, independent on the copper content in the studied samples. The distinct amorphization of the zeolitic structures led to the drastic deterioration of exchange capacity of such modified catalysts.

The presence of $\mathrm{Cu}^{+}$in our samples subjected to FT-IR studies originates from the so-called "auto-reduction" of $\mathrm{Cu}^{2+}$ species in vacuum at high temperature $\left(400{ }^{\circ} \mathrm{C}\right.$ and higher) in the absence of a reducing agent. This phenomenon takes place during the activation procedure prior to the FT-IR measurements of our Cu-samples with adsorbed probe molecules. The auto-reduction mechanism of divalent copper species was previously described for $\mathrm{Cu}$-loaded both zeolites [59] and alumina [60]. For comparison, in the $\mathrm{H}_{2}$ TPR results (Figure 5), we observed direct reduction of $\mathrm{Cu}^{2+}$ species to $\mathrm{Cu}^{0}$ (without the formation of $\mathrm{Cu}^{+}$which is generally difficult to keep stable). This ostensible contradiction between TPR and FT-IR data is due to different pretreatment conditions. In the former case, an activation prior to the $\mathrm{H}_{2}$-TPR experiment was performed in the absence of vacuum (in a helium flow) at much lower temperature compared to FT-IR measurements $\left(100{ }^{\circ} \mathrm{C}\right.$ vs. $400{ }^{\circ} \mathrm{C}$ in vacuum). Hence, during the activation preceding $\mathrm{H}_{2}$-TPR experiment, the auto-reduction of divalent $\mathrm{Cu}$ species did not take place.

In our previous work [61], we reported that for the sample in protonic form and containing $1 \%$ wt. of $\mathrm{Cu}\left(\mathrm{Cu}_{1} \mathrm{H}-\mathrm{Z}\right)$, the concentration of $\mathrm{Cu}^{+}$was twice smaller compared to the $\mathrm{Cu}$ content originating from its introduction by the impregnation method (160 $\mu \mathrm{mol} / \mathrm{g})$. This phenomenon may be explained by the fact that in our zeolite (FAU31), $\mathrm{Cu}^{+}$ may be located both in supercages and inside hexagonal prisms and cuboctahedra. The latter location of cations makes them inaccessible to adsorbed particles, such as $\mathrm{CO}$. The "hidden" sites are occupied by cations in the first place, due to the highest effectiveness of the stabilization of cations by framework oxygens in these positions. 
In the case of samples containing higher $\mathrm{Cu}$ contents $(2$ and $5 \% \mathrm{wt}$. both for protonic and sodium series), lower amount of $\mathrm{Cu}$ interacting with $\mathrm{CO}$ in relation to the total copper content introduced during impregnation may be also explained by the status of $\mathrm{Cu}$ species found in our FAU-31-based samples. It was indicated that the copper was in the form both of cations in exchange positions $\left(\mathrm{Cu}^{+}{ }_{\text {exch }}, \mathrm{Cu}^{2+}{ }_{\text {exch. }}\right)$ and in the form of oxides $\left(\mathrm{Cu}^{+}{ }_{\text {oxide, }}\right.$ $\mathrm{CuO})$. Zeolites in sodium form $\left(\mathrm{Cu}_{x} \mathrm{Na}-\mathrm{Z}\right)$ were characterized by much lower $\mathrm{Cu}^{+}{ }_{\text {exch }}$. contents and higher amounts of $\mathrm{Cu}^{+}$and $\mathrm{Cu}^{2+}$ in the oxide forms [61].

The differential IR spectra of the $\mathrm{CO}$ adsorbed at $-100{ }^{\circ} \mathrm{C}$ on $\mathrm{Cu}$-zeolite samples $\left(\mathrm{Cu}_{\mathrm{x}} \mathrm{H}-\mathrm{Z}\right)$ are presented in Figure 8 . The adsorption of $\mathrm{CO}$ resulted in the appearance of the following bands: $v_{\text {asym }}$ at $2153 \mathrm{~cm}^{-1}$ and $v_{\text {sym }}$ at $2175 \mathrm{~cm}^{-1}$, corresponding to dicarbonyls $\mathrm{Cu}^{+}(\mathrm{CO})_{2}$ formed at higher $\mathrm{CO}$ loadings $[62,63]$. The occurrence of new bands at 2165 and $2193 \mathrm{~cm}^{-1}$ assigned to tricarbonyls $\mathrm{Cu}^{+}(\mathrm{CO})_{3}$ was also found $[64,65]$. The intensity of the mentioned bands increases along with the increased $\mathrm{Cu}$ content in a similar way as in the case of bands at $2160 \mathrm{~cm}^{-1}$ corresponding to $\mathrm{Cu}^{+}(\mathrm{CO})$, which were recorded at room temperature (Figure 7).

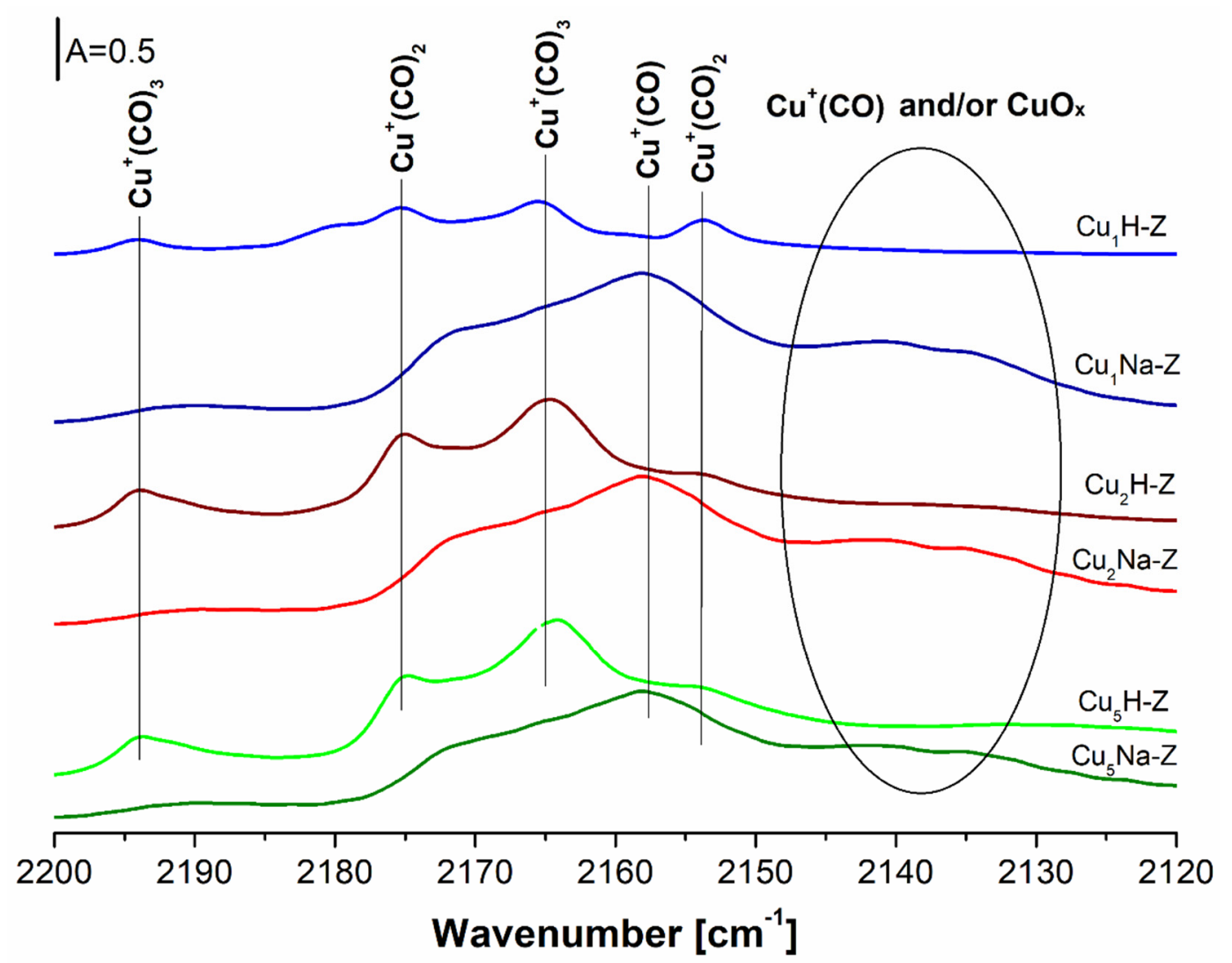

Figure 8. IR spectra of $\mathrm{CO}$ adsorbed at $-100{ }^{\circ} \mathrm{C}$ on the surface of $\mathrm{Cu}$-zeolite samples.

For the samples additionally pretreated with $\mathrm{NaNO}_{3}\left(\mathrm{Cu}_{\mathrm{x}} \mathrm{Na}-\mathrm{Z}\right)$, the bands at 2158, 2135 and $2140 \mathrm{~cm}^{-1}$ were registered (Figure 8). While the band at $2158 \mathrm{~cm}^{-1}$ was assigned to $\mathrm{Cu}^{+}(\mathrm{CO})$, the interpretation of the bands at 2135 and at $2140 \mathrm{~cm}^{-1}$ was not straightforward. They may be assigned to another kind of copper site [66] or to the associated $\mathrm{Cu}$ ions [67]. Datka et al. [62] evidenced simultaneous occurrence of species by the presence of the bands at 2158 and $2135 \mathrm{~cm}^{-1}$ which allowed us to suppose that the adsorption of $\mathrm{CO}$ was not an equilibrium process at low temperature $\left(-100^{\circ} \mathrm{C}\right)$. $\mathrm{CO}$ interacted with copper by adsorbing on all accessible sites. Subsequently, the redistribution took place: $\mathrm{CO}$ desorbed from sites of lower adsorption heat and re-adsorbed on sites having higher binding energy. Due to the low rate of desorption at $-100{ }^{\circ} \mathrm{C}$ (requiring $\mathrm{CO}$ molecules to 
overcome the activation energy), the redistribution was also slow. Góra-Marek et al. [68] suggested that the bands at ca $2130 \mathrm{~cm}^{-1}$ may correspond to $\mathrm{CuO}_{\mathrm{x}}$ species.

In all cases $\left(\mathrm{Cu}_{x} \mathrm{H}-\mathrm{Z}, \mathrm{Cu}_{x} \mathrm{Na}-\mathrm{Z}\right)$, the absence of the bands at 2206 and $2124 \mathrm{~cm}^{-1}$ proves that neither $\mathrm{Cu}^{0}$ nor $\mathrm{Cu}^{2+}$ species were present in the studied systems.

In our previous work [69], we reported the FT-IR analysis of Cu containing FAU31 zeolites in order to investigate the process of reduction of $\mathrm{Cu}$ sites with hydrogen and the properties of reduced zeolites. IR spectra of $\mathrm{OH}$ groups for two types of $\mathrm{Cu}$-zeolites: in protonic $\left(\mathrm{Cu}_{\mathrm{x}} \mathrm{H}-\mathrm{Z}\right)$ and sodium form $\left(\mathrm{Cu}_{\mathrm{x}} \mathrm{Na}-\mathrm{Z}\right)$ were recorded. In all cases, the reduction of $\mathrm{Cu}$ sites with hydrogen resulted in the formation of Brønsted acid sites- the growth of IR bands of acidic hydroxyls was observed. Furthermore, quantitative analysis $\left(\mathrm{NH}_{3}\right.$ sorption) indicated the production of protonic acidity, which agreed with the fact that $\mathrm{OH}$ bands increased. The formation mechanism of protonic acidity may be explained by the reduction of copper species $\left(\mathrm{Cu}^{+}{ }_{\text {exch }}, \mathrm{Cu}^{+}{ }_{\text {oxide, }} \mathrm{Cu}^{2+}\right)$ with hydrogen according to the reactions, as follows: $2 \mathrm{Cu}^{+}+\mathrm{H}_{2}=2 \mathrm{Cu}^{0}+2 \mathrm{H}^{+}$and $\mathrm{Cu}^{2+}+\mathrm{H}_{2}=\mathrm{Cu}^{0}+2 \mathrm{H}^{+}$. Furthermore, based on FT-IR studies of $\mathrm{CO}$ and NO sorption over $\mathrm{Cu}$-FAU31 zeolites, it was indicated that the susceptibility of $\mathrm{Cu}$ sites for the reduction with hydrogen depended strictly on the type of $\mathrm{Cu}$ species. Order of reduction $\mathrm{Cu}$ sites formed the following sequence: $\mathrm{Cu}^{+}{ }_{\text {oxide }}>$ $\mathrm{Cu}^{2+}>\mathrm{Cu}^{+}{ }_{\text {exch }}[69]$.

\subsection{Catalytic Properties}

Table 2 gathers the results of the catalytic tests for all four types of the samples: $\mathrm{H}-\mathrm{Z}$ containing only Brønsted and Lewis acid sites coming from zeolite, $\mathrm{Cu}_{2} \mathrm{H}-\mathrm{Z}$ containing both protonic and Lewis acid sites including also copper redox active centers, $\mathrm{Na}-\mathrm{Z}$ samples possessing only Lewis acid sites originating from zeolite structure and $\mathrm{Cu}_{2} \mathrm{Na}-\mathrm{Z}$ containing Lewis acid sites from both zeolite and copper species.

Table 2. Catalytic properties in dependence on reaction temperature and the presence of active center types in the studied samples.

\begin{tabular}{ccccccc}
\hline \multirow{2}{*}{ Sample } & \multicolumn{2}{c}{ Conversion [\%] } & \multicolumn{2}{c}{$\mathbf{Y}_{\text {Furan }}[\%]$} & \multicolumn{2}{c}{$\mathbf{Y}_{\text {2-methylfuran }}[\%]$} \\
\cline { 2 - 6 } & $\mathbf{3 0 0}{ }^{\circ} \mathbf{C}$ & $\mathbf{4 0 0}{ }^{\circ} \mathbf{C}$ & $\mathbf{3 0 0}{ }^{\circ} \mathbf{C}$ & $\mathbf{4 0 0}{ }^{\circ} \mathbf{C}$ & $\mathbf{3 0 0}{ }^{\circ} \mathbf{C}$ & $\mathbf{4 0 0}{ }^{\circ} \mathbf{C}$ \\
\hline $\mathrm{H}-Z$ & 33 & 77 & 16 & 60 & 0 & 0 \\
$\mathrm{Cu}_{2} \mathrm{H}-\mathrm{Z}$ & 73 & 64 & 22 & 28 & 1 & 1 \\
$\mathrm{Na}-\mathrm{Z}$ & 0 & 0 & 0 & 0 & 0 & 0 \\
$\mathrm{Cu}_{2} \mathrm{Na}-\mathrm{Z}$ & 53 & 56 & 10 & 14 & 2 & 2 \\
\hline
\end{tabular}

The data obtained at $300{ }^{\circ} \mathrm{C}$ (Table 2) indicated that Brønsted acid sites and copper active sites were similarly responsible for the catalytic activity of the studied materials. The best catalytic properties were found for the system containing both protonic and copper active sites $\left(\mathrm{Cu}_{2} \mathrm{H}-\mathrm{Z}\right)$, for which the conversion of furfural was $73 \%$, while furan yield was $22 \%$. Somewhat worse catalytic properties were observed for the sample containing only acid sites attributed to zeolitic structure (H-Z). Conversion of furfural and yield of furan were $33 \%$ and $16 \%$, respectively. In the case of the "Brønsted -free" catalyst (Na-Z) no catalytic activity was found, which evidenced no catalytic participation of Lewis acid sites assigned to $\mathrm{Al}$ species in this reaction. In turn, the presence of the copper redox sites in sodium form of FAU31-type zeolite $\left(\mathrm{Cu}_{2} \mathrm{Na}-\mathrm{Z}\right)$ resulted in an apparent furfural conversion $(53 \%)$, but very low furan yield $(10 \%)$ in comparison with protonic counterpart $\left(\mathrm{Cu}_{2} \mathrm{H}-\mathrm{Z}\right)$.

The increase of temperature up to $400{ }^{\circ} \mathrm{C}$ resulted in a significant improvement of catalytic properties of the parent sample $(\mathrm{H}-\mathrm{Z})$, for which furfural conversion and furan yield rose from 33 to $77 \%$ and from 16 to $60 \%$, respectively. For the catalyst containing both protonic acidity and copper active sites $\left(\mathrm{Cu}_{2} \mathrm{H}-\mathrm{Z}\right)$, the conversion of furfural decreased slightly from 73 to $64 \%$ and furan yield rose from slightly from 22 to $28 \%$, respectively. When the reaction was carried out over $\mathrm{Cu}_{2} \mathrm{Na}-\mathrm{Z}$ catalyst, higher temperature led to a very slight increase of both the conversion of furfural and furan yield (from 53 to $56 \%$ and from 
10 to $14 \%$, respectively). At $400{ }^{\circ} \mathrm{C}$, no catalytic activity was found for the sodium sample (Na-Z).

Next, the influence of the amount of copper on the catalytic activity was checked-See Tables 3 and 4 . For the catalysts containing both protonic acid sites and copper active centers $\left(\mathrm{Cu}_{\mathrm{x}} \mathrm{H}-\mathrm{Z}-\right.$ Table 3$)$, the appearance of copper in FAU31 zeolite led to increase of both conversion of furfural (from 33 to $73-78 \%$ ) and yield of furan (from 16 to $18-36 \%$ ) at $300{ }^{\circ} \mathrm{C}$. Nevertheless, the increase of the copper content led to significant deterioration in furan yield from $36 \%\left(\mathrm{Cu}_{1} \mathrm{H}-\mathrm{Z}\right)$ to $18 \%\left(\mathrm{Cu}_{5} \mathrm{H}-\mathrm{Z}\right)$.

Table 3. The influence of $\mathrm{Cu}$ content and temperature on catalytic properties of Brønsted acid sites-containing samples.

\begin{tabular}{ccccccc}
\hline \multirow{2}{*}{ Sample } & \multicolumn{2}{c}{ Conversion [\%] } & \multicolumn{2}{c}{$\mathbf{Y}_{\text {Furan }}[\%]$} & \multicolumn{2}{c}{$\mathbf{Y}_{\text {2-methylfuran }}[\%]$} \\
\cline { 2 - 7 } & $\mathbf{3 0 0}{ }^{\circ} \mathbf{C}$ & $\mathbf{4 0 0}{ }^{\circ} \mathbf{C}$ & $\mathbf{3 0 0}{ }^{\circ} \mathbf{C}$ & $\mathbf{4 0 0}{ }^{\circ} \mathbf{C}$ & $\mathbf{3 0 0}{ }^{\circ} \mathbf{C}$ & $\mathbf{4 0 0}{ }^{\circ} \mathbf{C}$ \\
\hline $\mathrm{H}-\mathrm{Z}$ & 33 & 77 & 16 & 60 & 0 & 0 \\
$\mathrm{Cu}_{1} \mathrm{H}-\mathrm{Z}$ & 78 & 64 & 36 & 23 & 0 & 0 \\
$\mathrm{Cu}_{2} \mathrm{H}-\mathrm{Z}$ & 73 & 64 & 22 & 28 & 1 & 1 \\
$\mathrm{Cu}_{5} \mathrm{H}-\mathrm{Z}$ & 74 & 64 & 18 & 19 & 1 & 1 \\
\hline
\end{tabular}

Table 4. The influence of $\mathrm{Cu}$ content and temperature on catalytic properties of Brønsted acid sites-free samples.

\begin{tabular}{ccccccc}
\hline \multirow{2}{*}{ Sample } & \multicolumn{2}{c}{ Conversion [\%] } & \multicolumn{2}{c}{$\mathbf{Y}_{\text {Furan }}[\%]$} & \multicolumn{2}{c}{$\mathbf{Y}_{\text {2-methylfuran }}[\%]$} \\
\cline { 2 - 6 } & $\mathbf{3 0 0}{ }^{\circ} \mathbf{C}$ & $\mathbf{4 0 0}{ }^{\circ} \mathbf{C}$ & $\mathbf{3 0 0}{ }^{\circ} \mathbf{C}$ & $\mathbf{4 0 0}{ }^{\circ} \mathbf{C}$ & $\mathbf{3 0 0}{ }^{\circ} \mathbf{C}$ & $\mathbf{4 0 0}{ }^{\circ} \mathbf{C}$ \\
\hline $\mathrm{Na}-\mathrm{Z}$ & 0 & 0 & 0 & 0 & 0 & 0 \\
$\mathrm{Cu}_{1} \mathrm{Na}-\mathrm{Z}$ & 47 & 21 & 7 & 0 & 2 & 1 \\
$\mathrm{Cu}_{2} \mathrm{Na}-\mathrm{Z}$ & 53 & 56 & 10 & 14 & 2 & 2 \\
$\mathrm{Cu}_{5} \mathrm{Na}-\mathrm{Z}$ & 71 & 60 & 9 & 5 & 4 & 3 \\
\hline
\end{tabular}

Elevation of reaction temperature up to $400{ }^{\circ} \mathrm{C}$ resulted in a slight decrease of furfural conversion from $73-78 \%$ to $64 \%$ and some changes in furan yield: from 36 to $23 \%$, from 22 to $28 \%$, and from 18 to $19 \%$ for $\mathrm{Cu}_{1} \mathrm{H}-\mathrm{Z} \mathrm{Cu} \mathrm{Cu}_{2} \mathrm{H}-\mathrm{Z}$ and $\mathrm{Cu}_{5} \mathrm{H}-\mathrm{Z}$, respectively. For the samples with higher copper content $\left(\mathrm{Cu}_{2} \mathrm{H}-\mathrm{Z}\right.$ and $\left.\mathrm{Cu}_{5} \mathrm{H}-\mathrm{Z}\right)$, trace of 2-methylfuran yield was found $(1 \%)$.

In the case of catalysts deprived of Brønsted acid sites $\left(\mathrm{Cu}_{x} \mathrm{Na}-\mathrm{Z}\right)$, studied at $300{ }^{\circ} \mathrm{C}$, the increase of the copper content from 1 to $5 \%$ wt. resulted in a significant improvement of furfural conversion ( $47 \mathrm{vs} .71 \%)$ without relevant changes of furan yield $(7-10 \%$-see Table 4). Furthermore, rising copper loading caused increasing (but still very low) of the 2-methylfuran yield (from 2 to $4 \%$ ).

At $400{ }^{\circ} \mathrm{C}$, the increase of copper loading from $1 \%$ wt. to $5 \%$ wt. led to higher furfural conversion from 21 to $60 \%$, but with very poor production of furan (5-14\%). Another effect of higher copper content was increasing yield of 2-methylfuran (from 1 to $3 \%$ ).

The application of the $\mathrm{Cu}$-containing catalysts implies from their lower hydrogenation ability compared with noble metals, which allows it to avoid the hydrogenation of furan ring $[70,71]$. The nature of the active species has been a subject of discussion for many years [72]. It was found that the $\mathrm{Cu}^{+} / \mathrm{Cu}^{0}$ ratio in the catalyst decides about catalytic activity. Rao et al. [73] indicated that the turnover frequency (TOF) decreased with lowering $\mathrm{Cu}^{+} / \mathrm{Cu}^{0}$ ratio from 0.3 to 0 over carbon-supported $\mathrm{Cu}$ catalysts. This phenomenon may be explained by the activation of $\mathrm{H}_{2}$ by metallic copper species, while $\mathrm{Cu}^{+}$sites plays a role of electrophilic or Lewis acid sites able to polarize $\mathrm{C}=\mathrm{O}$ bond via electron lone pair of oxygen $[74,75]$. The $\mathrm{Cu}^{+} / \mathrm{Cu}^{0}$ ratio depends strongly on many factors, such as the kind of support, the way of preparation and the conditions of catalytic tests (including reduction meant as a pretreatment procedure). 
In our previous work [61], we reported the status and properties of $\mathrm{Cu}$ species in HFAU and $\mathrm{NaFAU}$ of $\mathrm{Si} / \mathrm{Al}=31$ by IR spectroscopy with $\mathrm{CO}$ and $\mathrm{NO}$ as probe molecules. Both $\mathrm{Cu}^{+}$and $\mathrm{Cu}^{2+}$ were found in the zeolites in the form both of exchange cations $\left(\mathrm{Cu}^{+}\right.$exch, $\mathrm{Cu}^{2+}{ }_{\text {exch. }}$ ) and in oxide form $\left(\mathrm{Cu}^{+}{ }_{\text {oxide }}, \mathrm{CuO}\right)$. The proportion between various forms of $\mathrm{Cu}$ depended significantly on both the amount of $\mathrm{Cu}$ introduced into the materials and the way of treatment of FAU-type zeolite (HFAU or NaFAU). In CuHFAU containing $1 \mathrm{wt} . \%$ of $\mathrm{Cu}$, all of $\mathrm{Cu}$ species were in the form of $\mathrm{Cu}^{+}{ }_{\text {exch }}$. neutralizing $\mathrm{AlO}_{4}{ }^{-}$. Higher copper content resulted in the co-existence of $\mathrm{Cu}^{+}{ }_{\text {oxide }}$ as well as the presence of $\mathrm{Cu}^{2+}$ as $\mathrm{Cu}^{2+}$ exch. and $\mathrm{CuO}$ species. Zeolites $\mathrm{Cu}_{\mathrm{x}} \mathrm{NaFAU}$ contained much lower amount of $\mathrm{Cu}^{+}$exch. and higher contribution of $\mathrm{Cu}^{+}$and $\mathrm{Cu}^{2+}$ in the oxide forms. Direct comparison of the data given in Table 4 led to the conclusion that $\mathrm{Cu}^{+}{ }_{\text {oxide }}$ and $\mathrm{CuO}$ are the most active $\mathrm{Cu}$ species in this reaction. Furthermore, copper oxide species favor slightly the formation of 2-methylfuran.

The results of the catalytic experiments described above indicate that two types of active sites present in the tested samples contribute to their catalytic activity. Decarbonylation of furfural is realized mainly on the protonic acid sites.

High activity of the H-Z sample in furfural decarbonylation should be attributed to the existence of strong Brønsted acid sites. The similar reactivity of samples of acidic character was reported earlier for catalysts based on zeolites and heteropolyacids-see, e.g., references [76-78] for reports on transformation of lactic acid and its derivatives to acetaldehyde. The activity in decarbonylation was ascribed to high density of acid sites which directly interact with the carbonyl group which is to be removed from the substrate.

Furfural decarbonylation to furan also proceeds on $\mathrm{Cu}$ sites.

Our findings are in line with the previous reports on the application of the copperbased systems to furfural hydrogenation and decarbonylation [79]. A similar effect was also found for $\gamma$-valerolactone valorization [80]. It is claimed that furfural can be activated on copper phase via $\mathrm{C}-\mathrm{H}$ bond rupture from the aldehyde group. Thus, formed furfuryl residue is stabilized on the metal center due to its interactions with un-filled orbitals of copper. The reactivity of furfural is also determined by the geometry of the substrate adsorption on the catalytic active sites [72].

Further, it is believed that the copper centers are also responsible for hydrogen activation during hydrogenation of biomass-derived products [80,81].

The contribution of copper redox active centers in the decarbonylation of furfural may be also explained by the production of Brønsted acid sites as a result the reduction of copper species with hydrogen according to the following reactions: $2 \mathrm{Cu}^{+}+\mathrm{H}_{2}=2 \mathrm{Cu}^{0}+$ $2 \mathrm{H}^{+}$and $\mathrm{Cu}^{2+}+\mathrm{H}_{2}=\mathrm{Cu}^{0}+2 \mathrm{H}^{+}$, which was reported in our previous work [69]. Protonic acid sites generated in this way could participate in the formation of furan.

We also investigated an effect of the application of the pretreatment in hydrogen (prior to catalytic experiment) on the catalytic behavior of the samples containing various copper content in protonic form- $-\mathrm{Cu}_{\mathrm{x}} \mathrm{H}-\mathrm{Z}$ (Table 5). It was indicated that for $\mathrm{Cu}$-containing catalysts, the use of hydrogen did not change furfural conversion (64\%), but caused a slight increase of furan yield from 19 to $23 \%$ or from 17 to $28 \%$ or from 11 to $19 \%$ for $\mathrm{Cu}_{1} \mathrm{H}-\mathrm{Z}$ or $\mathrm{Cu}_{2} \mathrm{H}-\mathrm{Z}$ or $\mathrm{Cu}_{5} \mathrm{H}-\mathrm{Z}$, respectively. Analysis of these results suggests that the pretreatment of our catalysts in hydrogen (directly before catalytic measurements) led to the formation of new protonic acid sites, which could enhance the production of furan.

Table 5. The influence of the application of pretreatment in hydrogen at $400{ }^{\circ} \mathrm{C}$ on catalytic properties of $\mathrm{Cu}$ containing HFAU31-type samples. The presented catalytic results refer to $400{ }^{\circ} \mathrm{C}$.

\begin{tabular}{ccccccc}
\hline Sample & \multicolumn{2}{c}{ Conversion [\%] } & \multicolumn{2}{c}{ Y Furan $_{\text {[\%] }}$} & \multicolumn{2}{c}{ Y 2-methylfuran $_{\text {[\%] }}$} \\
\hline Activation in $\mathbf{H}_{\mathbf{2}}$ & No & Yes & No & Yes & No & Yes \\
\hline $\mathrm{H}-\mathrm{Z}$ & - & 77 & - & 60 & - & 0 \\
$\mathrm{Cu} \mathrm{u}_{1} \mathrm{H}-\mathrm{Z}$ & 64 & 64 & 19 & 23 & 0 & 0 \\
$\mathrm{Cu}_{2} \mathrm{H}-\mathrm{Z}$ & 64 & 64 & 17 & 28 & 3 & 1 \\
$\mathrm{Cu}_{5} \mathrm{H}-\mathrm{Z}$ & 64 & 64 & 11 & 19 & 4 & 1 \\
\hline
\end{tabular}


All studied catalysts revealed very high susceptibility to coking (Tables 2-5). This effect was particularly strong for $\mathrm{Cu}$-containing catalysts and generally increased with the amount of copper in the prepared samples. Deactivation is the main problem for $\mathrm{Cu}$-based hydrogenation catalysts, which hampers their industrial application. This phenomenon also occurs over the catalysts containing acid sites like zeolites [81]. Hence, it is possible that newly created protonic acid sites take part in the production of coke. It may be also related with the loss of the $\mathrm{Cu}^{+}$species by the reduction and poisoning of active $\mathrm{Cu}$ sites by the adsorption of reaction intermediates.

In order to determine how the studied catalysts changed after the reaction, we performed XRD, SEM and FT-IR experiments for the spent samples. The results concerning the crystallinity, morphology, acidic properties and an optical appearance of the catalysts after catalytic experiments are summarized in Appendix A (Figures A1-A4).

In all cases, the analysis of XRD data (Figure A1) indicated that, during catalytic tests, the crystallinity of the studied samples underwent a drastic deterioration probably due to the interaction between vaporized furfural and very a sensitive structure of FAU31-type zeolite. Final crystallinity was ca $9 \%$ for the samples in protonic series $\left(\mathrm{H}-\mathrm{Z}\right.$ and $\left.\mathrm{Cu}_{5} \mathrm{H}-\mathrm{Z}\right)$, while $\mathrm{Cu}_{5} \mathrm{Na}-\mathrm{Z}$ was characterized by zero crystallinity.

For the parent sample $(\mathrm{H}-\mathrm{Z})$, the contact with the reaction mixture led to apparent changes in its morphology (Figure A2). Well defined edges of irregular-shaped crystals were subjected to blurring, which could be an effect of the FAU31 amorphization.

Comparison of FT-IR spectra of pyridine adsorbed on fresh and spent $\mathrm{H}-\mathrm{Z}$ catalyst led to the conclusion that studies catalyst underwent coking. The decrease of the bands assigned to the acid sites was probably due to blocking of acid sites by coke depositions.

Last evidence for the coking of the studied catalysts is a direct comparison of the optical appearance of samples before and after catalytic experiment (Figure A4). Both $\mathrm{Cu}$-free and samples containing $\mathrm{Cu}$ became black during catalytic tests.

For the $\mathrm{H}-\mathrm{Z}$ catalyst, a stability test was performed at $350{ }^{\circ} \mathrm{C}$ (Table A1). From the presented data, it may be concluded that the investigated catalyst was not highly stable due to coking. Both furfural conversion and yield of furan decreased from 74 to $35 \%$ and from 61 to $26 \%$, respectively. The deterioration of catalytic properties of the studied sample during the time of experiment was in line with the loss of Brønsted acid sites accessibility (Figure A3), as well as corresponded to the changes in the crystallinity (Figure A1) and morphology (Figure A2) of the studied catalyst.

\section{Materials and Methods}

\subsection{Catalysts Preparation}

We obtained four types of catalytic systems (Table 6). A commercial ultrastabilized and dealuminated zeolite with FAU type structure (molar Si / Al ratio was 31) from Zeolyst, denoted as $\mathrm{H}-\mathrm{Z}$, was applied as a carrier. The sample contains only the zeolitic acid centers.

Table 6. The occurrence of different active center types in dependence on the preparation of the sample.

\begin{tabular}{ccc}
\hline \multirow{2}{*}{ Sample } & \multicolumn{2}{c}{ The Presence of } \\
\cline { 2 - 3 } & Brønsted & Copper Active Sites \\
\hline $\mathrm{H}-\mathrm{Z}$ & yes & no \\
$\mathrm{Cu} \mathrm{u}_{\mathrm{x}} \mathrm{H}-\mathrm{Z}$ & yes & yes \\
$\mathrm{Na}-\mathrm{Z}$ & no & no \\
$\mathrm{Cu} \mathrm{u}_{\mathrm{x}} \mathrm{Na}-\mathrm{Z}$ & no & yes \\
\hline
\end{tabular}

$\mathrm{x}=1,2,5 \%$ wt. $\mathrm{Cu}$.

Sodium form of FAU31 zeolite (designated as Na-Z) is deprived of protonic acid centers. It contains only Lewis acid sites coming from zeolite structure (Al species); thus, it may be used as a reference sample. It was obtained by 5 -fold ion-exchange of $\mathrm{H}-\mathrm{Z}$ with 0.5 $\mathrm{M} \mathrm{NaNO}_{3}$ at $80^{\circ} \mathrm{C}$ for $2 \mathrm{~h}$. The mass of solution was 30 -fold higher compared to zeolite. Subsequently, the sample was 4-fold centrifuged $(\mathrm{RPM}=4000)$ and dried at $60^{\circ} \mathrm{C}$ for $3 \mathrm{~h}$. 
Cu-containing Na-Z samples (denoted as $\mathrm{Cu}_{1} \mathrm{Na}-\mathrm{Z}, \mathrm{Cu}_{2} \mathrm{Na}-\mathrm{Z}$ and $\mathrm{Cu}_{5} \mathrm{Na}-\mathrm{Z}$, where numerals mean \%wt. of $\mathrm{Cu}$ ) have both Lewis acid sites originating from both zeolite structure and redox active $\mathrm{Cu}$ centers. $\mathrm{Na}-\mathrm{Z}$ was impregnated with $0.5 \mathrm{M} \mathrm{Cu}\left(\mathrm{NO}_{3}\right)_{2} \cdot 3 \mathrm{H}_{2} \mathrm{O}$, dried at $120^{\circ} \mathrm{C}$ and, finally, calcined at $500{ }^{\circ} \mathrm{C}$ for $8 \mathrm{~h}$.

In the case of samples for which pretreatment with $\mathrm{NaNO}_{3}$ was omitted (direct impregnation with aqueous copper nitrate solution under the same conditions as described above), all discussed active centers are present. The samples doped with 1,2 and 5\%wt. of $\mathrm{Cu}$ were denoted as $\mathrm{Cu}_{1} \mathrm{H}-\mathrm{Z}, \mathrm{Cu}_{2} \mathrm{H}-\mathrm{Z}$ and $\mathrm{Cu}_{5} \mathrm{H}-\mathrm{Z}$, respectively.

\subsection{Catalysts Characterization}

The XRD measurements were carried out at room temperature using diffractometer PANalytical X'Pert PRO (Malvern Panalytical Ltd., Malvern, United Kingdom) MPD with $\mathrm{CuK} \alpha$ radiation $\left(\lambda=1.5418 \AA\right.$ ) at $40 \mathrm{kV}$ and $30 \mathrm{~mA}$ and with $2 \theta$ range from 5 to $50^{\circ}$ with $0.033^{\circ}$ step for $12 \mathrm{~min}$. The researched zeolite samples were in powder form and were placed in holders. The crystallinity changes of prepared samples were determined by the integration of the reflexes in the $2 \theta$ range of $5-50^{\circ}$ in XRD patterns. XRD images are presented in Figures 2 and A2 (in Appendix A).

The ${ }^{27} \mathrm{Al}$ MAS NMR experiments were performed on hydrated zeolites by the exposition to the vapor of a saturated aqueous $\mathrm{Mg}\left(\mathrm{NO}_{3}\right)_{2}$ solution. The ${ }^{27} \mathrm{Al}$ MAS NMR spectra were acquired at resonance frequency of $130.3 \mathrm{MHz}$, on a Bruker Advance III $500 \mathrm{MHz}$ WB spectrometer (Bruker Corporation, Billerica, MA, USA). ${ }^{27} \mathrm{Al}$ MAS NMR spectra were recorded at a spinning rate of the samples in zirconia rotors of $12 \mathrm{kHz}$ with a short pulse length of $0.2 \mu \mathrm{s}(\pi / 12)$ and a recycle delay of $0.1 \mathrm{~s}$. The chemical shifts were externally referenced to $1 \mathrm{M}$ aqueous aluminum nitrate solution. ${ }^{27} \mathrm{Al}$ MAS NMR spectra are given in Figure 3.

The low-temperature sorption of nitrogen was carried out using Quantachrome Nova 2000 (Quantachrome Instruments, now Anton Paar GmbH, Graz, Austria). Prior to the experiment, the samples were evacuated for $20 \mathrm{~h}$ at $300^{\circ} \mathrm{C}$ in vacuum. Micropore volume $\left(\mathrm{V}_{\text {micro }}\right)$ and external surface Area $\left(\mathrm{S}_{\mathrm{EXT}}\right)$ were calculated using t-plot method. Pore size distribution and micro-and mesopores volume $\left(\mathrm{V}_{\text {micro }}, \mathrm{V}_{\text {meso }}\right)$ were determined by the utilization of $\mathrm{BJH}$ model to the adsorption branch of the isotherm. The results of porous structure measurements are summarized in Table 1.

The SEM experiments were carried out using Jeol JSM-7500F scanning electron microscope (JEOL Ltd., Tokyo, Japan) equipped with the X-ray energy dispersive (EDS) system INCAPentaFETx3 (JEOL Ltd., Tokyo, Japan). Two detectors were used and the images were recorded in two modes; the secondary electron detector provided SEI images and backscattered electron detector provided BSE (COMPO) micrographs. The samples were dried for $24 \mathrm{~h}$ and coated with chromium $(20 \mathrm{~nm})$ directly before measurements. SEM micrographs are given in Figures 4 and A2 (in Appendix A).

The TPR profiles of the catalysts were obtained using U-type quartz reactor with a Quantachrome Chembet-300 apparatus (Quantachrome Instruments, now Anton Paar $\mathrm{GmbH}$, Graz, Austria). All samples ( $25 \mathrm{mg}$ each) were activated in helium flow at $100{ }^{\circ} \mathrm{C}$ for $1.5 \mathrm{~h}$. Subsequently, the samples were heated $\left(\right.$ at $10^{\circ} \mathrm{C} / \mathrm{min}$.) in the flow of reduction mixture $\left(5 \%\right.$ of $\mathrm{H}_{2}$ in Ar) to the final temperature $600^{\circ} \mathrm{C}$. The hydrogen consumption was monitored using TCD detector. The results referring to the reducibility of copper species in the studied catalysts are depicted in Figure 5.

The FT-IR analysis was conducted using Nicolet 6700 spectrometer with MCT detector from Thermo Scientific (Thermo Fisher Scientific, Waltham, MA, USA). Before the FT-IR experiments, the samples in the form of thin wafers were activated for $1 \mathrm{~h}$ at $400{ }^{\circ} \mathrm{C}$ in vacuum. The $\mathrm{CO}$ or $\mathrm{NH}_{3}$ gases (Air Products $99.5 \%$ and $99.3 \%$, respectively) and pyridine (Sigma-Aldrich Chemie GmbH, Taufkirchen, Germany, 99.8\%) were used as adsorbates. Small doses of $\mathrm{CO}$ were adsorbed on the surface of sample both at $-100^{\circ} \mathrm{C}$ and at room temperature. Procedure of ammonia or pyridine adsorption was carried out at 130 or $170^{\circ} \mathrm{C}$, respectively. The amount of probe molecules introduced into the IR cell was calculated from 
the ideal gas law. The quantitative analyses of Brønsted and Lewis acidity were performed according to the procedures, which detailed description was reported in $[17,48,68]$. Either qualitative or quantitative analyses of the FT-IR analysis of adsorbed probe molecules are illustrated in Figures 6-8 and Figure A3 (in Appendix A) and in Table 1.

\subsection{Catalytic Tests}

Catalytic studies of hydrogenation and decarbonylation of furfural to furan and 2methylfuran were performed in a fixed-bed quartz microreactor. The experiments were done at atmospheric pressure and in the temperature range of $300-400{ }^{\circ} \mathrm{C}$ for $30 \mathrm{~min}$ at given temperature. For each experiment $0.5 \mathrm{~mL}$ of catalyst (particles sizes in the range of 400 to 500 microns) was placed on a quartz wool plug in the reactor (with an inner diameter of $8 \mathrm{~mm}$ and length of $32 \mathrm{~cm}$ ) and reduced in a $25 \mathrm{~mL} / \mathrm{min}$ flow of pure hydrogen at $400{ }^{\circ} \mathrm{C}$ for $2 \mathrm{~h}$. Subsequently, it was applied a gaseous mixture containing $0.23 \mathrm{mg} / \mathrm{min}$ of furfural (SAFC, $\geq 98.0 \%$ ) in $\mathrm{H}_{2}$ with total flow rate of $50 \mathrm{~mL} / \mathrm{min}$. WHSV equaled to $6000 \mathrm{~h}^{-1}$. The concentration of furfural, furan and 2-methylfuran as the main reaction products were continuously measured using gas chromatography SRI8610A model with FID detector SRI Instruments, Torrance, CA, USA).

The furfural conversion $\left(\mathrm{X}_{\mathrm{FAL}}\right)$, furan and 2-methylfuran yields $\left(\mathrm{Y}_{\mathrm{F}}, \mathrm{Y}_{2-\mathrm{MF}}\right)$ were calculated according to the following equations:

$$
\begin{aligned}
\mathrm{X}_{\mathrm{FAL}} & =\left(\mathrm{N}_{\mathrm{FAL}}{ }^{\text {in }}-\mathrm{N}_{\mathrm{FAL}}{ }^{\text {out }}\right) / \mathrm{N}_{\mathrm{FAL}}{ }^{\text {in }} * 100 \% \\
\mathrm{Y}_{\mathrm{F}} & =\mathrm{N}_{\mathrm{F}}{ }^{\text {out }} /\left(\mathrm{N}_{\mathrm{FAL}}{ }^{\text {in }}-\mathrm{N}_{\mathrm{FAL}}{ }^{\text {out }}\right) * 100 \% \\
\mathrm{Y}_{2-\mathrm{MF}} & =\mathrm{N}_{2-\mathrm{MF}}{ }^{\text {out }} /\left(\mathrm{N}_{\mathrm{FAL}}{ }^{\text {in }}-\mathrm{N}_{\mathrm{FAL}}{ }^{\text {out }}\right) * 100 \%
\end{aligned}
$$

where $\mathrm{N}_{\mathrm{FAL}}{ }^{\text {in }}$ and $\mathrm{N}_{\mathrm{FAL}}$ out are moles of furfural before and after the reaction, respectively. In turn, $\mathrm{N}_{\mathrm{F}}{ }^{\text {out }}$ and $\mathrm{N}_{2-\mathrm{MF}}$ out are moles of products produced during the reaction: furan or 2-methylfuran, respectively. Prior to the catalytic experiments, blank tests including the contribution of quartz wool as well as a bare reactor on the catalytic behavior were per -formed. In the catalytic data summarized in Tables 3-6, the effects attributed to blank tests have been taken account.

\section{Conclusions}

We have obtained the systems containing none, one or two types of active centers i.e., Brønsted acid sites and "redox" copper species. Treatment of parent FAU31 zeolite (H-Z) with $\mathrm{NaNO}_{3}$ aq. sol. (Na-Z) resulted in the removal of Brønsted acid sites.

Direct synthesis of furan from furfural was catalyzed both by copper-exchanged and copper-free dealuminated faujasite type zeolite. Brønsted acid sites were mainly responsible for the catalytic activity in the whole temperature range. No contribution of Lewis acid sites associated with zeolitic aluminum in catalytic activity was found. The presence of the redox copper centers led to the appearance of trace amounts of 2-methylfuran as the result of the partial hydrogenation of furfural. Coke formation was found, probably resulting from the polymerization of furfural. The presence of coper in the studied catalysts promoted coking. Further studies dedicated to the nature of furfural polymers will be done in the nearest future.

Author Contributions: Conceptualization, Ł.K. and D.R.-Z.; methodology, Ł.K., M.S.-U., J.K., W.R., J.P., K.S., D.D., M.Z., M.G. and D.R.-Z.; software, Ł.K.; validation, Ł.K., M.S.-U., J.K., W.R., J.P., K.S, D.D., M.Z., M.G. and D.R.-Z.; formal analysis, Ł.K., M.G. and D.R.-Z.; investigation, Ł.K., M.S.-U., J.K., W.R., J.P., K.S., D.D., M.Z., M.G. and D.R.-Z.; data curation, Ł.K.; writing-original draft preparation, Ł.K. and D.R.-Z.; writing—review and editing, Ł.K. and D.R.-Z.; visualization, Ł.K.; supervision, Ł.K. and D.R.-Z. All authors have read and agreed to the published version of the manuscript.

Funding: The work was done within the statutory funds from the Jerzy Haber Institute of Catalysis and Surface Chemistry, Polish Academy of Sciences. 
Institutional Review Board Statement: Not applicable.

Informed Consent Statement: Not applicable.

Data Availability Statement: Not applicable.

Conflicts of Interest: The authors declare no conflict of interest.

Sample Availability: Samples of the compounds of $\mathrm{Cu}$ containing zeolites of FAU type structure are available from the authors.

\section{Appendix A}

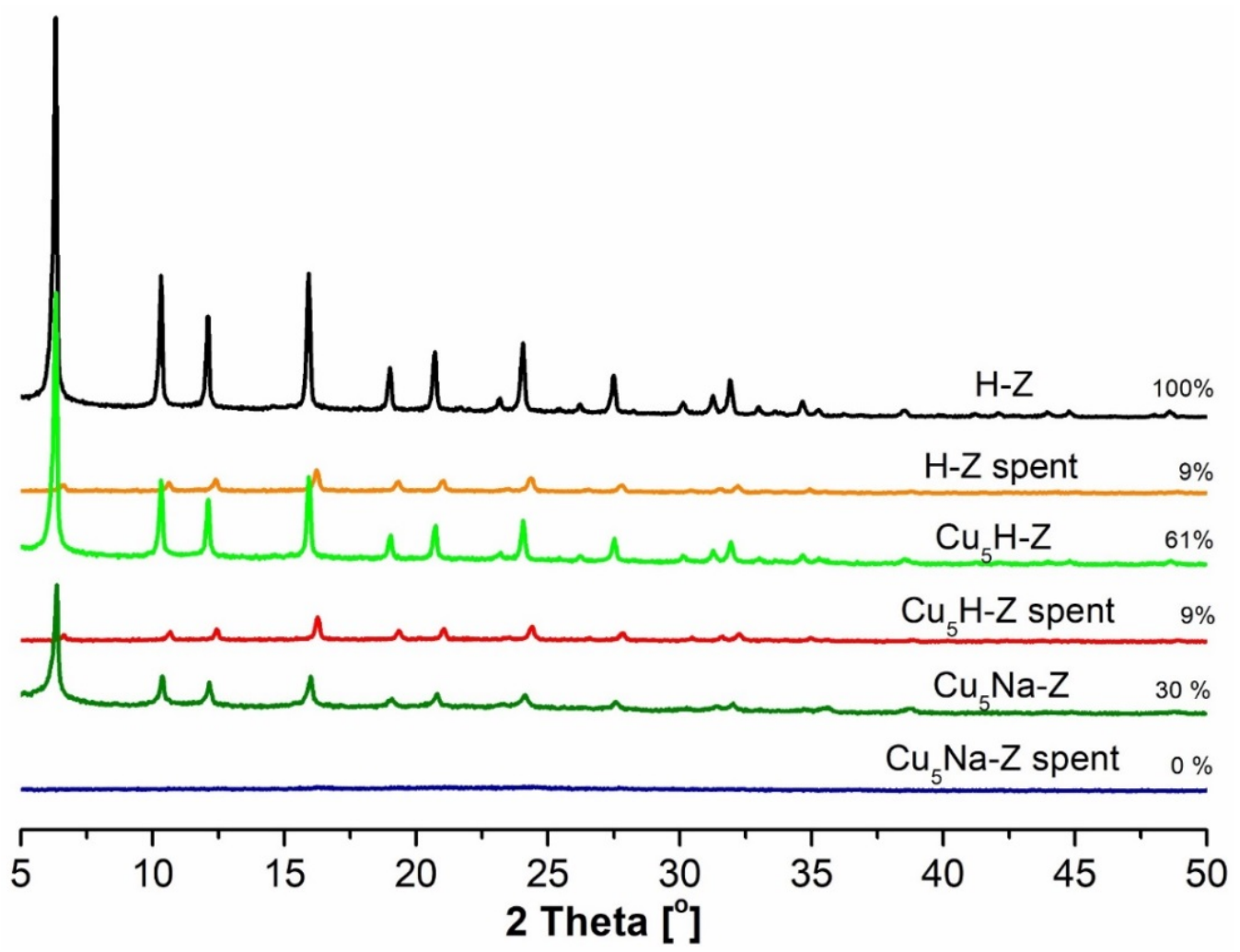

Figure A1. XRD images of the chosen samples before and after catalytic studies. 

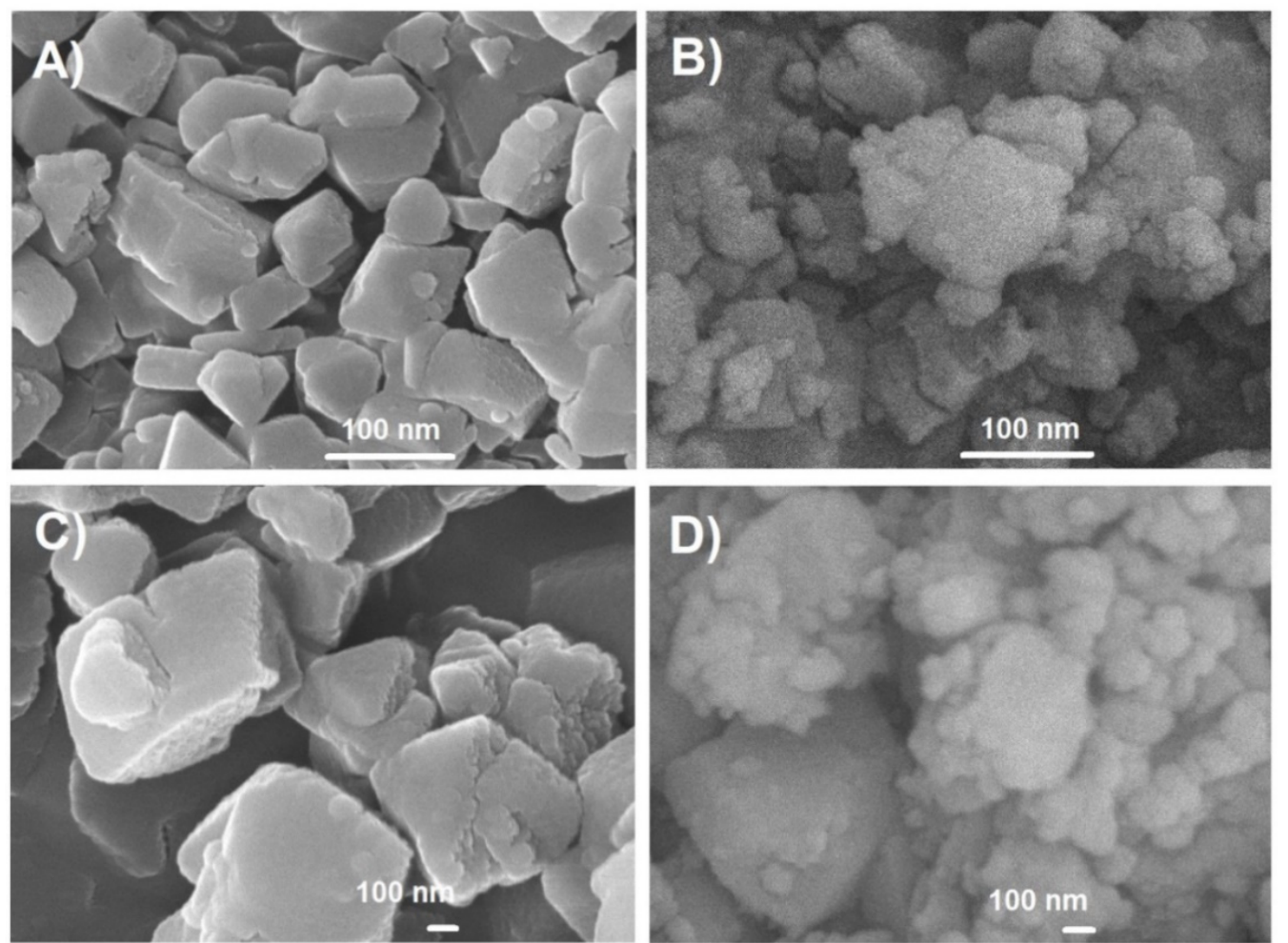

Figure A2. SEM images of the parent sample: fresh H-Z: (A) 25,000 x, (B) 50,000 x; spent H-Z: (C) 25,000 x, (D) 50,000 x.

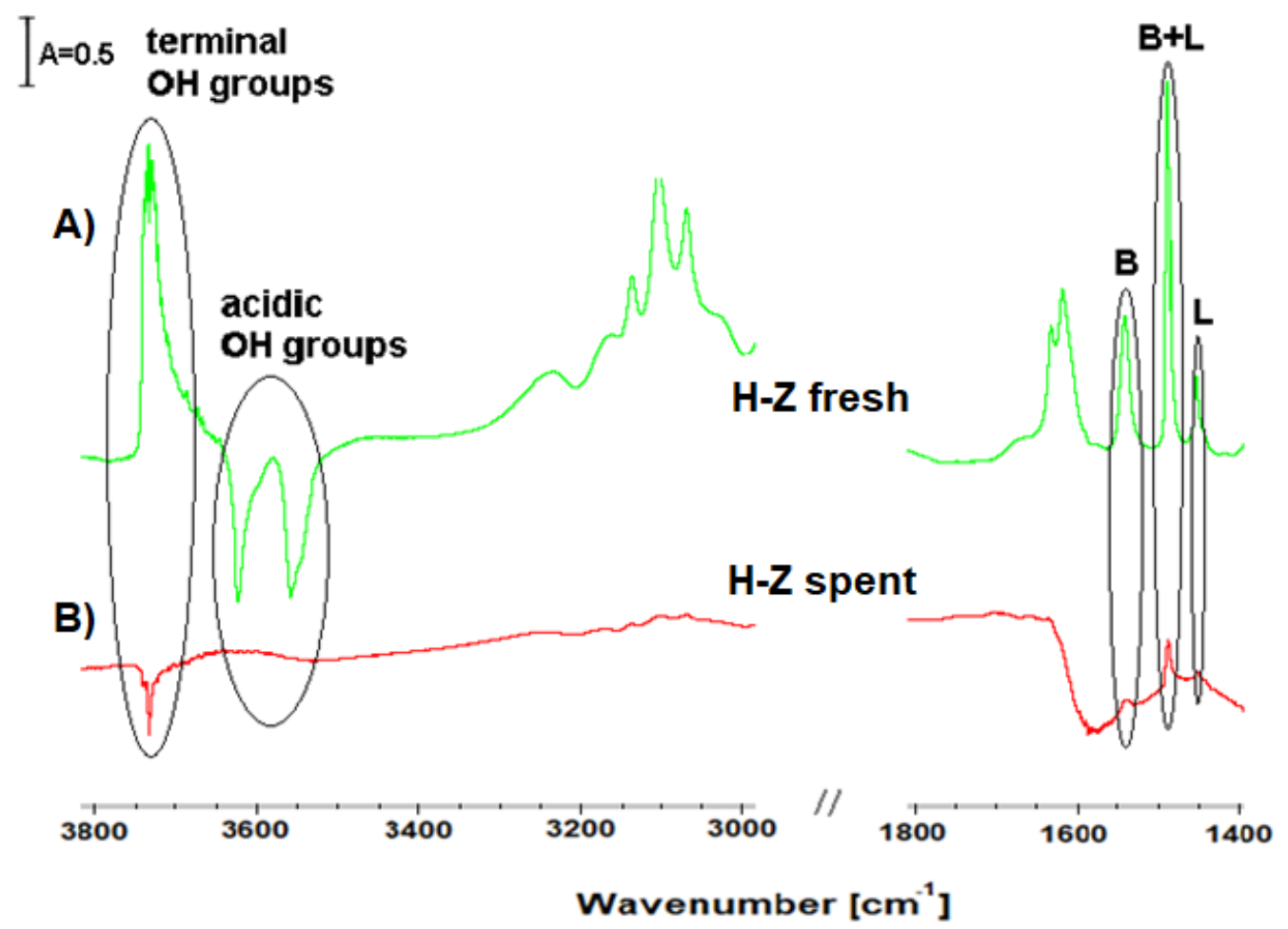

Figure A3. FT-IR spectra of the H-Z catalyst: (A) fresh sample, (B) spent sample (after reaction). 


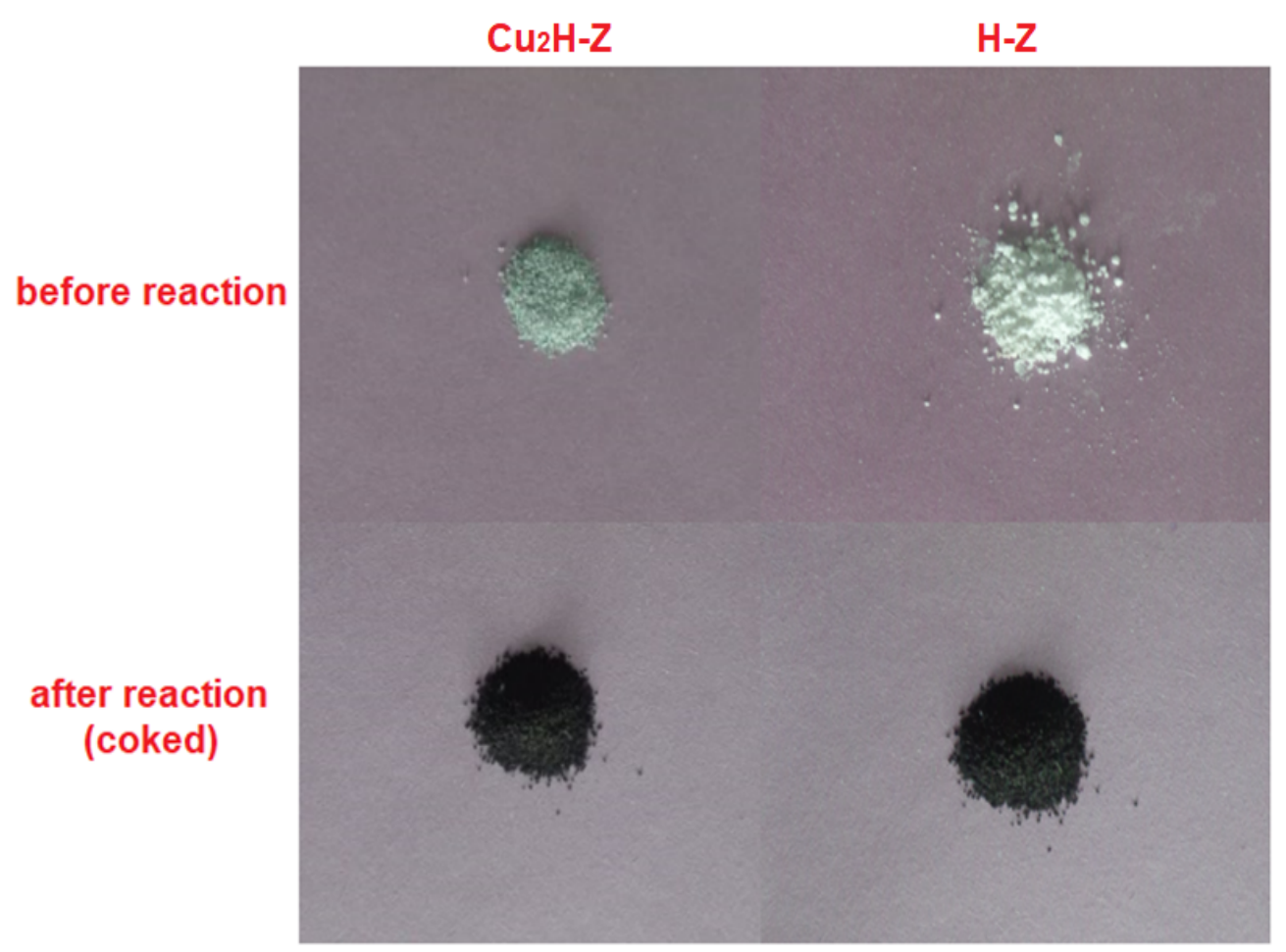

Figure A4. An optical evidence for the coking of the investigated samples during catalytic experiments.

Table A1. Stability test for the $\mathrm{H}-\mathrm{Z}$ catalyst at $350^{\circ} \mathrm{C}$.

\begin{tabular}{cccc}
\hline Time [h] & Conversion [\%] & Y Furan $_{\text {[\%] }}$ & Y 2-methylfuran $_{\text {[\%] }}$ \\
\hline 0 & 74 & 61 & 0 \\
1 & 55 & 42 & 0 \\
2 & 44 & 36 & 0 \\
3 & 39 & 29 & 0 \\
4 & 38 & 27 & 0 \\
5 & 36 & 27 & 0 \\
6 & 36 & 26 & 0 \\
7 & 35 & 26 & 0 \\
\hline
\end{tabular}
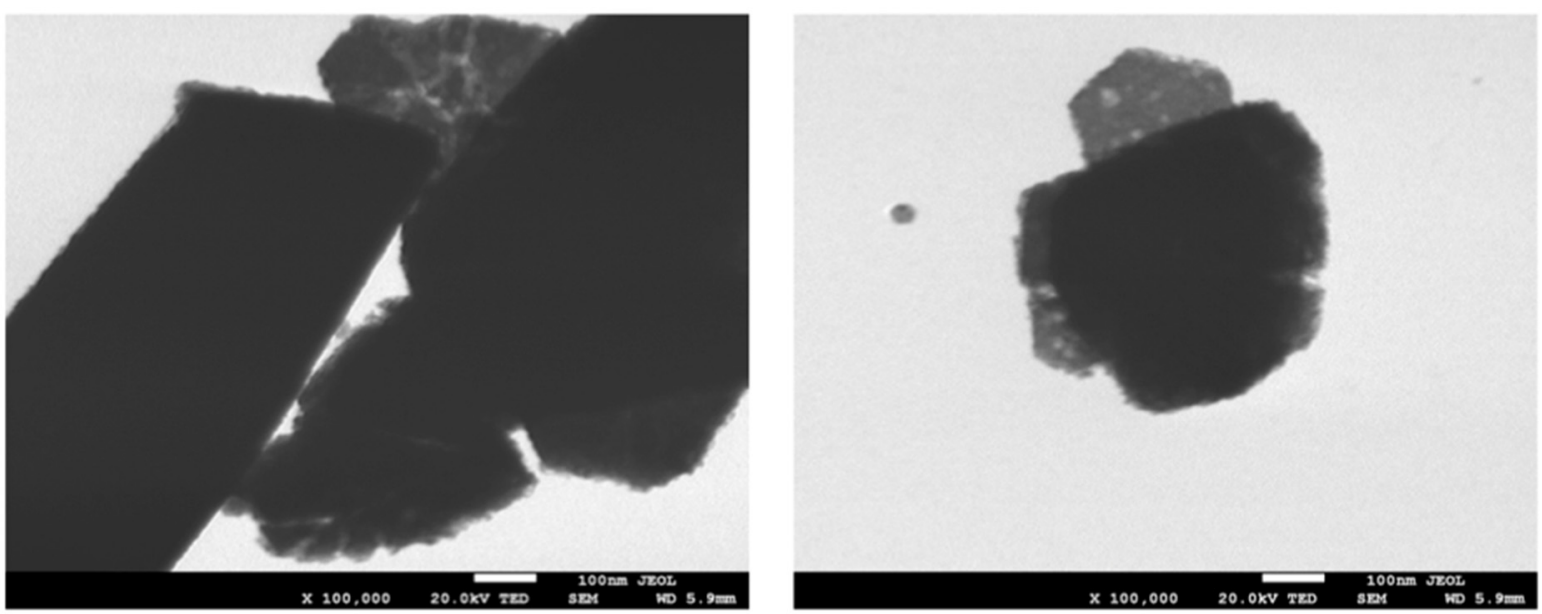

Figure A5. TEM images of the H-Z sample. 


\section{References}

1. Hoydonckx, H.E.; Van Rhijn, W.M.; Van Rhijn, W.; De Vos, D.E.; Jacobs, P.A. Furfural and derivatives. In Ullmann's Encyclopedia of Industrial Chemistry; Wiley-VCH Verlag GmbH \& Co. KGaA: Weinheim, Germany, 2007; p. 285. [CrossRef]

2. Mandalika, A.S. Enabling the Development of Furan-Based Biorefineries. Master's Thesis, University of Wisconsin Madison, Madison, WI, USA, 2012. Available online: https://minds.wisconsin.edu/bitstream/handle/1793/63313/mandalika_masters_ thesis.pdf? sequence=1\&isAllowed $=y$ (accessed on 10 March 2021).

3. Yan, K.; Wu, G.; Lafleur, T.; Jarvis, C. Production, properties and catalytic hydrogenation of furfural to fuel additives and value-added chemicals. Renew. Sustain. Energy Rev. 2014, 38, 663-676. [CrossRef]

4. Yan, K.; Lafleur, T.; Liao, J.; Xie, X. Facile Green Synthesis of Palladium Nanoparticles for Efficient Liquid-Phase Hydrogenation of Biomass-Derived Furfural. Sci. Adv. Mater. 2014, 6, 135-140. [CrossRef]

5. Mariscal, R.; Maireles-Torres, P.; Ojeda, M.; Sádaba, I.; López Granados, M. Furfural: A renewable and versatile platform molecule for the synthesis of chemicals and fuels. Energy Environ. Sci. 2016, 9, 1144-1189. [CrossRef]

6. Zhao, Y.L.; Zhang, W.L.; Su, X.L. Catalytic decarbonylation of furfural to furan over a palladium catalyst. Petrochem. Technol. 1999, $28,293$.

7. Singh, H.; Prasad, M.; Srivastava, R.D. Metal support interactions in the palladium catalysed decomposition of furfural to furan J. Chem. Technol. Biotechnol. 1980, 30, 293-296. [CrossRef]

8. Zeitsch, K.J. The Chemistry and Technology of Furfural and Its Many By-Products, 1st ed.; Elsevier Science: Amsterdam, The Netherlands, 2000.

9. Bhogeswararao, S.; Srinivas, D. Catalytic conversion of furfural to industrial chemicals over supported Pt and Pd catalysts. J. Catal. 2015, 327, 65-77. [CrossRef]

10. Wilson, C.L. Reactions of furan compounds. Part V. Formation of furan from furfuraldehyde by the action of nickel or cobalt catalysts: Importance of added hydrogen. J. Chem. Soc. 1945, 3, 61-63. [CrossRef]

11. Lejemble, P.; Gaset, A.; Kalck, P. From biomass to furan through decarbonylation of furfural under mild conditions. Biomass 1984, 4, 263-274. [CrossRef]

12. Hurd, C.D.; Goldsby, A.R.; Osborne, E.N. Furan reactions. II. Furan from furfural. J. Am. Chem. Soc. 1932, 54, 2532-2536. [CrossRef]

13. Fanchiang, W.L.; Lin, Y.C. Catalytic fast pyrolysis of furfural over H-ZSM-5 and Zn/H-ZSM-5 catalysts. Appl. Catal. A 2012, 419-420, 102-110. [CrossRef]

14. Seo, G.; Chon, H. Hydrogenation of furfural over copper-containing catalysts. J. Catal. 1981, 67, 424-429. [CrossRef]

15. Ruppert, J.P. Electron Spin Resonance Spectra of Interlamellar Copper(ll)-Arene Complexes on Montmorillonite. J. Phys. Chem. 1973, 77, 784-790. [CrossRef]

16. Kladning, W. Surface acidity of cation exchanged Y-zeolites. J. Phys. Chem. 1976, 80, 262-269. [CrossRef]

17. Gackowski, M.; Kuterasiński, Ł.; Podobiński, J.; Sulikowski, B.; Datka, J. IR and NMR studies of hierarchical material obtained by the treatment of zeolite Y by ammonia solution. Spectrochim. Acta A 2018, 193, 440-446. [CrossRef]

18. Kaushik, V.M.; Ravindranathan, M. XPS study of copper-containing Y zeolites for the hydration of acrylonitrile to acrylamide. Zeolites 1992, 12, 415-419. [CrossRef]

19. Maxwell, I.E.; Downing, R.S.; van Langen, S.A.J. Copper-exchanged zeolite catalysts for the cyclodimerization of butadiene: II. Catalyst structure. J. Catal. 1980, 61, 485-502. [CrossRef]

20. Pestryakov, A.N.; Lunin, V.V. Physicochemical study of active sites of metal catalysts for alcohol partial oxidation. J. Mol. Catal. A: Chem. 2000, 158, 325-329. [CrossRef]

21. Lepore, A.W.; Li, Z.; Davison, B.H.; Foo, G.-S.; Wu, Z.; Narula, C.K. Catalytic Dehydration of Biomass Derived 1-Propanol to Propene over M-ZSM-5 (M = H, V, Cu, or Zn). Ind. Eng. Chem. Res. 2017, 56, 4302-4308. [CrossRef]

22. Kyriienko, P.I.; Larina, O.V.; Soloviev, S.O.; Orlyk, S.M.; Calers, C.; Dzwigaj, S. Ethanol Conversion into 1,3-Butadiene by the Lebedev Method over MTaSiBEA Zeolites (M = Ag, Cu, Zn). ACS Sustain. Chem. Eng. 2017, 5, 2075-2083. [CrossRef]

23. Rodrigues de Oliveira, T.K.; Rosset, M.; Perez-Lopez, O.W. Ethanol dehydration to diethyl ether over Cu-Fe/ZSM-5 catalysts. Catal. Commun. 2018, 104, 32-36. [CrossRef]

24. Klein, A.; Keisers, K.; Palkovits, R. Formation of 1,3-butadiene from ethanol in a two-step process using modified zeolite- $\beta$ catalysts. Appl. Catal. A Gen. 2016, 514, 192-202. [CrossRef]

25. Singh, L.; Rekha, P.; Chand, S. Cu-impregnated zeolite Y as highly active and stable heterogeneous Fenton-like catalyst for degradation of Congo red dye. Sep. Purif. Technol. 2016, 170, 321-336. [CrossRef]

26. Sazama, P.; Moravkova, J.; Sklenak, S.; Vondrova, A.; Tabor, E.; Sadovska, G.; Pilar, R. Effect of the Nuclearity and Coordination of $\mathrm{Cu}$ and Fe Sites in $\beta$ Zeolites on the Oxidation of Hydrocarbons. ACS Catal. 2020, 10, 3984-4002. [CrossRef]

27. Palomino, G.; Bordiga, S.; Zecchina, A.; Marra, G.L.; Lamberti, C. XRD, XAS, and IR Characterization of Copper-Exchanged Y Zeolite. J. Phys. Chem. B 2000, 104, 8641-8651. [CrossRef]

28. Broclawik, E.; Datka, J.; Gil, B.; Piskorz, W.; Kozyra, P. The interaction of CO, $\mathrm{N}_{2}$ and NO with Cu cations in ZSM-5: Quantum chemical description and IR study. Top. Catal. 2000, 11, 335-341. [CrossRef]

29. Sárkány, J.; D'Itri, J.L.; Sachtler, W.M.H. Redox chemistry in excessively ion-exchanged Cu/Na-ZSM-5. Catal. Lett. 1992, 16, 241-249. [CrossRef] 
30. Dedecek, J.; Sobalik, Z.; Tvaruazkova, Z.; Kaucky, D.; Wichterlova, B. Coordination of Cu Ions in High-Silica Zeolite Matrixes. $\mathrm{Cu}^{+}$Photoluminescence, IR of NO Adsorbed on $\mathrm{Cu}^{2+}$, and $\mathrm{Cu}^{2+}$ ESR Study. J. Phys. Chem. 1995, 99, 16327-16337. [CrossRef]

31. Wichterlová, B.; Dědeček, J.; Sobalík, Z.; Vondrová, A.; Klier, K. On the Cu Site in ZSM-5 Active in Decomposition of NO: Luminescence, FTIR Study, and Redox Properties. J. Catal. 1997, 169, 194-202. [CrossRef]

32. Anpo, M.; Matsuoka, M.; Shioya, Y.; Yamashita, H.; Giamello, E.; Morterra, C.; Che, M.; Patterson, H.; Webber, S.; Ouellette, S.; et al. Preparation and Characterization of the $\mathrm{Cu}^{+} /$ZSM-5 Catalyst and Its Reaction with NO under UV Irradiation at $275 \mathrm{~K}$. In Situ Photoluminescence, EPR, and FT-IR Investigations. J. Phys. Chem. 1994, 98, 5744-5750. [CrossRef]

33. Dědeček, J.; Wichterlová, B. Siting and Redox Behavior of Cu Ions in CuH-ZSM-5 Zeolites. Cu+ Photoluminescence Study. J. Phys. Chem. 1994, 98, 5721-5727. [CrossRef]

34. Janas, J.; Gurgul, J.; Socha, R.P.; Dźwigaj, S. Effect of Cu content on the catalytic activity of CuSiBEA zeolite in the SCR of NO by ethanol: Nature of the copper species. Appl. Catal. B 2009, 91, 217-224. [CrossRef]

35. Sojka, Z.; Che, M.; Giamello, E. EPR Investigation of the Electronic Structure of Mononuclear Copper(I) Nitric Oxide Adduct Formed upon Low-Pressure Adsorption of NO onto Cu/ZSM-5 Zeolite. J. Phys. Chem. B 1997, 101, 4831-4838. [CrossRef]

36. Groothaert, M.H.; Van Bokhoven, J.A.; Battiston, A.A.; Weckhuysen, B.M.; Schoonheydt, R.A. Bis( $\mu$-oxo)dicopper in Cu-ZSM-5 and Its Role in the Decomposition of NO: A Combined in Situ XAFS, UV-Vis-Near-IR, and Kinetic Study. J. Am. Chem. Soc. 2003, 125, 7629-7640. [CrossRef]

37. Datka, J.; Kukulska-Zajac, E. IR Studies of the Activation of CC Bond in Alkenes by $\mathrm{Cu}^{+}$Ions in Zeolites. J. Phys. Chem. B 2004, 108, 17760-17766. [CrossRef]

38. Datka, J.; Kukulska-Zajac, E.; Kobyzewa, W. The activation of acetylene by $\mathrm{Cu}^{+}$ions in zeolites studied by IR spectroscopy. Catal. Today 2005, 101, 123-129. [CrossRef]

39. Kukulska-Zając, E.; Datka, J. Transformations of Formaldehyde Molecules in Cu-ZSM-5 Zeolites. J. Phys. Chem. C 2007, 111, 3471-3475. [CrossRef]

40. Kukulska-Zajac, E.; Kozyra, P.; Datka, J. The interaction of benzene with $\mathrm{Cu}^{+}$sites in zeolites: IR studies and DFT quantum chemical calculations. Appl. Catal. A Gen. 2006, 307, 46-50. [CrossRef]

41. Kazansky, V.B.; Pidko, E.A. A new insight in the unusual adsorption properties of $\mathrm{Cu}^{+}$cations in Cu-ZSM-5 zeolite. Catal. Today 2005, 110, 281-293. [CrossRef]

42. Kozyra, P.; Piskorz, W. A comparative computational study on hydrogen adsorption on the $\mathrm{Ag}^{+}, \mathrm{Cu}^{+}, \mathrm{Mg}^{2+}, \mathrm{Cd}^{2+}, \mathrm{and}^{2+}$ cationic sites in zeolites. Phys. Chem. Chem. Phys. 2016, 18, 12592-12603. [CrossRef] [PubMed]

43. Ordomsky, V.V.; Cai, M.; Sushkevich, V.; Moldovan, S.; Ersen, O.; Lancelot, C.; Valtchev, V.; Khodakov, A.Y. The role of external acid sites of ZSM-5 in deactivation of hybrid CuZnAl/ZSM-5 catalyst for direct dimethyl ether synthesis from syngas. Appl. Catal. A. Gen 2014, 486, 266-275. [CrossRef]

44. Miletto, I.; Catizzone, E.; Bonura, G.; Ivaldi, C.; Migliori, M.; Gianotti, E.; Marchese, L.; Frusteri, F.; Giordano, G. In Situ FT-IR Characterization of CuZnZr/Ferrierite Hybrid Catalysts for One-Pot $\mathrm{CO}_{2}$-to-DME Conversion. Materials 2018, $11,2275$. [CrossRef] [PubMed]

45. Downs, R.T.; Hall-Wallace, M. The American Mineralogist crystal structure database. Am. Mineral. 2003, 88, $247-250$.

46. Silaghi, M.C.; Chizallet, C.; Petracovschi, E.; Kerber, T.; Sauer, J.; Raybaud, P. Regioselectivity of Al-O Bond Hydrolysis during Zeolites Dealumination Unified by Brønsted-Evans-Polanyi Relationship. ACS Catal. 2015, 5, 11-15. [CrossRef]

47. Gackowski, M.; Tarach, K.; Kuterasiński, Ł.; Podobiński, J.; Jarczewski, S.; Kuśtrowski, P.; Datka, J. Hierarchical zeolites Y obtained by desilication: Porosity, acidity and catalytic properties. Microporous Mesoporous Mater. 2018, 263, 282-288. [CrossRef]

48. Kuterasiński, Ł.; Rojek, W.; Gackowski, M.; Zimowska, M.; Jodłowski, P.J. Sonically modified hierarchical FAU-type zeolites as active catalysts for the production of furan from furfural. Ultrason. Sonochem. 2020, 60, 104785. [CrossRef]

49. Van Aelst, J.; Haouas, M.; Gobechiya, E.; Houthoofd, K.; Philippaerts, A.; Sree, S.P.; Kirschhock, C.E.A.; Jacobs, P.; Martens, J.A.; Sels, B.F.; et al. Hierarchization of USY Zeolite by $\mathrm{NH}_{4} \mathrm{OH}$. A Postsynthetic Process Investigated by NMR and XRD. J. Phys. Chem. $C$ 2014, 118, 22573-22582. [CrossRef]

50. Bourgeat-Lami, E.; Massiani, P.; Di Renzo, F.; Espiau, P.; Fajula, F.; Courières, T.D. Study of the state of aluminium in zeolite beta. Appl. Catal. 1991, 72, 139-152. [CrossRef]

51. Mahoney, F.; Rudham, R.; Summers, J.V. Hydrogen oxidation catalysed by X zeolite containing transition metal ions. J. Chern. Soc. Faraday 1979, 75, 314-322. [CrossRef]

52. Wichterlova, B.; Tvaruzkova, Z.; Novakova, J. Chromium ions within zeolites. Part 1. Infrared, electron spin resonance and temperature-programmed reduction studies of the valence states of chromium ions. J. Chem. Soc. Faraday Trans. 1983, 79, 1573-1583. [CrossRef]

53. Jacobs, P.A.; Linart, J.P.; Nijs, H.; Uytterhoeven, J.B. Redox behaviour of transition metal ions in zeolites. Part 5. Method of quantitative determination of bidisperse distributions of metal particle sizes in zeolites. J. Chem. Soc. Faraday Trans. 1977, 73, 1745-1754. [CrossRef]

54. Gentry, S.J.; Hurst, N.W.; Jones, A. Temperature programmed reduction of copper ions in zeolites. J. Chem. Soc. Faraday Trans. 1979, 75, 1688-1699. [CrossRef]

55. Jacobs, P.A.; Tielen, M.; Linart, J.P.; Uytterhoeven, J.B.; Beyer, H. Redox behaviour of transition metal ions in zeolites. Part 4. Kinetic study of the reduction and reoxidation of copper-Y zeolites. J. Chem. Soc. Faraday Trans. 1976, 72, 2793-2804. [CrossRef] 
56. Lercher, J.A.; Grundling, C.; Eder-Mirth, G. Infrared studies of the surface acidity of oxides and zeolites using adsorbed probe molecules. Catal. Today 1996, 27, 353-376. [CrossRef]

57. Medin, A.S.; Borovkov, Y.V.; Kazansky, V.B.; Pelmentschikov, A.G.; Zhidomirov, G.M. On the unusual mechanism of Lewis acidity manifestation in HZSM-5 zeolites. Zeolites 1990, 10, 668-673. [CrossRef]

58. Sibi, M.P.; Cook, G.R. Copper Lewis Acids in Organic Synthesis; Wiley Online Library: John Wiley \& Sons, Inc.: Hoboken, NJ, USA, 2000; ISBN 9783527618309.

59. Sushkevich, V.L.; Smirnov, A.V.; Van Bokhoven, J.A. Autoreduction of Copper in Zeolites: Role of Topology, Si/Al Ratio, and Copper Loading. J. Phys. Chem. C 2019, 123, 9926-9934. [CrossRef]

60. Amano, F.; Tanaka, T.; Funabiki, T. Auto-reduction of $\mathrm{Cu}(\mathrm{II})$ species supported on $\mathrm{Al} 2 \mathrm{O} 3$ to $\mathrm{Cu}(\mathrm{I})$ by thermovacuum treatment. J. Mol. Catal. A Chem. 2004, 221, 89-95. [CrossRef]

61. Kuterasiński, Ł.; Podobiński, J.; Rutkowska-Zbik, D.; Datka, J. IR Studies of the Cu Ions in Cu-Faujasites. Molecules 2019, 24, 4250. [CrossRef]

62. Datka, J.; Gil, B.; Kawałek, M.; Staudte, B. Low temperature IR studies of CO sorbed in ZSM-5 zeolites. J. Mol. Struct. 1999, 511, 133-139. [CrossRef]

63. Spoto, G.; Zecchina, A.; Bordiga, S.; Ricchiardi, G.; Martra, G.; Leoffanti, G.; Pertini, G. Cu(I)-ZSM-5 zeolites prepared by reaction of $\mathrm{H}-\mathrm{ZSM}-5$ with gaseous $\mathrm{CuCl}$ : Spectroscopic characterization and reactivity towards carbon monoxide and nitric oxide. Appl. Catal. B 1994, 3, 151-172. [CrossRef]

64. Lamberti, C.; Bordiga, S.; Salvalaggio, M.; Spoto, G.; Zecchina, A.; Geobaldo, F.; Vlacic, G.; Bellatreccia, M. XAFS, IR, and UV-Vis Study of the CuI Environment in CuI-ZSM-5. J. Phys. Chem. B 1997, 101, 344-360. [CrossRef]

65. Zecchina, A.; Bordiga, S.; Salvalaggio, M.; Spoto, G.; Scarano, D.; Lamberti, C. Formation of Nonplanar CuI(CO)3 Tricarbonyls on CuI-ZSM-5: An FTIR Study at 80 K. J. Catal. 1998, 173, 540-542. [CrossRef]

66. Itho, Y.; Nishiyama, S.; Tsuruya, S.; Masai, M. Redox behavior and mobility of copper ions in NaZSM-5 zeolite during oxidation. J. Phys. Chem. 1994, 98, 960-967. [CrossRef]

67. Hadjiivanov, K.I.; Kantcheva, M.M.; Klissurski, D.G. IR study of CO adsorption on Cu-ZSM-5 and CuO/SiO 2 catalysts: $\sigma$ and $\pi$ components of the Cu+-CO bond. J. Chem. Soc. Faraday Trans. 1996, 92, 4595-4600. [CrossRef]

68. Góra-Marek, K.; Palomares, A.E.; Glanowska, A.; Sadowska, K.; Datka, J. Copper sites in zeolites-Quantitative IR studies. Microporous Mesoporous Mater. 2012, 162, 175-180. [CrossRef]

69. Kuterasiński, Ł.; Podobiński, J.; Madej, E.; Smoliło-Utrata, M.; Rutkowska-Zbik, D.; Datka, J. Reduction and Oxidation of Cu Species in Cu-faujasites Studied by IR Spectroscopy. Molecules 2020, 25, 4765. [CrossRef]

70. Rao, R.; Dandekar, A.; Baker, R.T.K.; Vannice, M.A. Properties of Copper Chromite Catalysts in Hydrogenation Reactions. J. Catal. 1997, 171, 406-419. [CrossRef]

71. Jimenez-Gomez, C.P.; Cecilia, J.A.; Marquez-Rodríguez, I.; Moreno-Tost, R.; Santamaría-Gonzalez, J.; Merida-Robles, J.; MairelesTorres, P. Gas-Phase Hydrogenation of Furfural over $\mathrm{Cu} / \mathrm{CeO}_{2}$ Catalysts. Catal. Today 2017, 279, 327-338. [CrossRef]

72. Chen, S.; Wojcieszak, R.; Dumeignil, F.; Marceau, E.; Royer, S. How Catalysts and Experimental Conditions Determine the Selective Hydroconversion of Furfural and 5-Hydroxymethylfurfural. Chem. Rev. 2018, 118, 11023-11117. [CrossRef]

73. Rao, R.S.; Baker, R.T.K.; Vannice, M.A. Furfural Hydrogenation over Carbon-Supported Copper. Catal. Lett. 1999, 60, 51-57. [CrossRef]

74. Dandekar, A.; Baker, R.T.K.; Vannice, M.A. Carbon Supported Copper Catalysts. J. Catal. 1999, 184, 421-439. [CrossRef]

75. Boronat, M.; May, M.; Illas, F. Origin of Chemoselective Behavior of S-Covered Cu(111) towards Catalytic Hydrogenation of Unsaturated Aldehydes. Surf. Sci. 2008, 602, 3284-3290. [CrossRef]

76. Sad, M.E.; González Peña, L.F.; Padró, C.L.; Apesteguía, C.R. Selective synthesis of acetaldehyde from lactic acid on acid zeolites. Catal. Today 2018, 302, 203-209. [CrossRef]

77. Katryniok, B.; Paul, S.; Dumeignil, F. Highly efficient catalyst for the decarbonylation of lactic acid to acetaldehyde. Green Chem. 2010, 12, 1910-1913. [CrossRef]

78. Murphy, B.M.; Letterio, M.P.; Xu, B. Catalytic dehydration of methyl lactate: Reaction mechanism and selectivity control. J. Catal 2016, 339, 21-30. [CrossRef]

79. Lukes, R.M.; Wilson, C.L. Some Optically Active Dodecahydrophenanthrenes. J. Am. Chem. Soc. 1951, 73, 4790-4794. [CrossRef]

80. Li, W.; Li, Y.Z.; Fan, G.L.; Yang, L.; Li, F. Role of Surface Cooperative Effect in Copper Catalysts toward Highly Selective Synthesis of Valeric Biofuels. ACS Sustain. Chem. Eng. 2017, 5, 2282-2291. [CrossRef]

81. Guisnet, M.; Magnoux, P. Deactivation of Zeolites by Coking. Prevention of Deactivation and Regeneration. In Zeolite Microporous Solids: Synthesis, Structure, and Reactivity; Derouane, e.g., Lemos, F., Naccache, C., Ribeiro, F.R., Eds.; NATO ASI Series (Series C: Mathematical and Physical Sciences); Springer: Dordrecht, The Netherlands, 1992; Volume 352, ISBN 978-94-011-2604-5. 